\title{
Damping Property of Carbon Fiber Reinforced Plastic for Noise/Vibration/Harsh of Steering Column Support Assembly
}

\section{Mingde Ding ( $\sim 987096806 @ q q . c o m$ )}

Chongqing University of Arts and Sciences

\section{Bo Liu}

Chongqing Changan Automobile Co Ltd

\section{Zhenhua Fan}

Chongqing polycomp international corp

\section{Jinyan Wang}

Dalian University of Technology

\section{Fuqiang Zhai}

Chongqing University of Arts and Sciences

Lu Li

Chongqing University of Arts and Sciences

\section{Original Article}

Keywords: Damping, CF reinforced PA66, NVH, Steering column support assembly, GF reinforced PA66

Posted Date: May 5th, 2021

DOI: https://doi.org/10.21203/rs.3.rs-459720/v1

License: (1) This work is licensed under a Creative Commons Attribution 4.0 International License. Read Full License 


\section{Title page}

\section{Damping Property of Carbon Fiber Reinforced Plastic for Noise/Vibration/Harsh of Steering Column Support Assembly}

Ming-De Ding, born in 1986, is currently a senior engineer at Chongqing University of Arts and Sciences and a PhD candidate at Dalian University of Technology, China. He received his master degree from Shandong University, China, in 2012. His research interests include composite materials and vehicle lightweight.

Tel: 13350322194; E-mail: 987096806@qq.com

Bo Liu, born in 1977, is currently a professor senior engineer at Chongqing Changan Automobile Co Ltd, China. He won the National Plan for Talented Persons of Ten Thousand Talents and the National outstanding scientific and technical workers, and received his PhD degree from Jilin University, China, in 2007.

E-mail: 150414213@qq.com

Zhen-Hua Fan, born in 1983, is currently a senior engineer at Chongqing Polycomp International Corp, China.

Jin-yan Wang, born in 1970, is currently a professor and a PhD candidate supervisor at Department of Polymer Science \& Materials, College of Chemical, China, won the National Plan for Talented Persons of Ten Thousand Talents. Her main research interests include high-performance resins and their composites, functional coatings, adhesives, and $3 \mathrm{D}$ printing materials that can withstand temperatures above $300^{\circ} \mathrm{C}$.

E-mail: wangjinyan@dlut.edu.cn

Fu-Qiang Zhai, born in 1985, is currently an associate research fellow at Chongqing University of Arts and Sciences, China. He received his $\mathrm{PhD}$ degree from Polytechnic University of Catalonia, Spanish, in 2015.

Lu Li, born in 1982, is currently a professor, the deputy director of Research Institute for New Materials Technology and the full-time deputy director of Co-innovation Center for Micro/Nano Optoelectronic Materials and Devices of Chongqing University of Arts and Sciences, China. He received his $\mathrm{PhD}$ degree from University of Electronic Science and Technology, was the post-doctor and the Researcher of University of California-Los Angeles. His research interests include optoelectronic materials and devices for displaying and lighting and those energy conversion devices, and the development and application of nanocomposite materials.

\section{Corresponding author: Bo Liu_E-mail: 150414213@qq.com Jin-yan Wang E-mail: wangiinyan@dlut.edu.cn}




\title{
Damping Property of Carbon Fiber Reinforced Plastic for Noise/Vibration/Harsh of Steering Column Support Assembly
}

\author{
Ming-de Ding ${ }^{1,2} \cdot$ Bo Liu $^{3} \cdot$ Zhen-hua Fan ${ }^{4} \cdot$ Jin-yan Wang ${ }^{1} \cdot$ Fu-qiang Zhai ${ }^{2} \cdot$ Lu Li $^{2}$
}

Received June xx, 201x; revised February xx, 201x; accepted March xx, 201x

(C) Chinese Mechanical Engineering Society and Springer-Verlag Berlin Heidelberg 2021

\begin{abstract}
Composite materials have penetrated into structural applications within the automotive industry, replacing traditional materials to reduce weight and then to improve fuel efficiency and to meet emission regulation. For some composite structural components, a significantly lower mode value compared to metal components can be accepted with an equivalent or better noise/vibration/harshness (NVH) performance, because, for composite materials, with different characteristics and much higher damping value compared to metal materials, a more sophisticated definition is required. An experimental investigation for mode definition of carbon fiber reinforced plastic (CFRP) steering column support assembly is discussed. Two kinds of composite steering column support assembly were manufactured, one is carbon fiber (CF) reinforced polyamide66 (PA66) with high mechanical properties, the other is glass fiber (GF) reinforced polyamide66 (PA66) with lower properties. The NVH test was carried out for these two components, and then the steering system mode requirement was defined by the test result. The new defined mode requirement obtained in the experiment showed good agreement with steering system mode analysis and test. By comparing the defined system mode requirement of composite component with that of the steel component, the effect of damping property of this composite material of the component

\footnotetext{
Jin-yan Wang wangjinyan@dlut.edu.cn

1 Department of Polymer Science \& Materials, College of Chemical Engineering, Dalian University of Technology, Dalian 116024, China

2 Chongqing Key Laboratory of Materials Surface \& Interface Science, Chongqing University of Arts and Sciences, China, Chongqing 402160, China

3 Chongqing Changan Automobile Co Ltd, China, Chongqing 401120, China
}

$\triangle$ Bo Liu 150414213@qq.com

4 Chongqing Polycomp International Corp, Chongqing 400084, China
\end{abstract}

can be clearly shown, which is over $21 \%$ percent on the NVH performance.

Keywords: Damping $-\mathrm{CF}$ reinforced PA66 $・$ NVH $・$ Steering column support assembly $\bullet \mathrm{GF}$ reinforced PA66

\section{Introduction}

The automotive industry is increasingly demanding for weight reduction as a result of demanding of new fuel-efficiency and emissions standards[1-2]. Composites can offer great deal of weight saving with respect to monolithic structural materials, and have been increased used by the automotive company in many vehicle parts such as door module, seat backs and spare-wheel well[3-9]. Recently, CFRP are a concern of the automotive industry and have become the predominant structural material, because of their high specific stiffness and strength. CFRP can provide much more weight reduction compared with other lightweight materials such as aluminum, high strength steel and GF reinforced plastics[10-14].

Construction of the automobile steering column support assembly is achieved which mainly includes the steering support cross tube, the steering column mounting bracket assembly, the left mounting bracket assembly, the right mounting bracket assembly and the central mounting bracket assembly. It is an important assembly part in the automobile, which provides the base architecture off which the steering column and IP components are attached and function. Due to the complexity of its design and its high performance requirement, the materials used for the production are metal, i.e. steel, magnesium, aluminum. Among these steel is most prevalent, but magnesium and aluminum are increasingly used due to the needs for weight reduction[15-16]. However, for steel and aluminum, 
the part integration is low and the production chain is long, there is tremendous need for component intensive. For magnesium, high degree integration can be achieved, but the cost of post treatment is high and then it is very hard to reduce cost[17]. Recently, composites especially CFRP are used to develop steering column support assembly to overcome the drawbacks of the metal component[18-20].

Regardless of its material of construction, the most demanding requirement for steering column support assembly is noise/vibration/harshness (NVH) test, because the steering column and various IP components are attached to it and function. The steering system mode was used to evaluate the NVH performance during the designing process. Due to the high damping of composite materials, the vibration attenuation of composite component is faster, and the forced vibration of composite component is lower at the resonance frequency[21-23]. Therefore, the mode requirement for composites steering column support assembly would be lower than that of metal component. However, it is very hard to test the damping value of the assembly[24-25], so we can't set the mode requirement based on the damping value. Then, we must find other easy method to affirm the mode requirement of composite steering column support assembly.

This paper describes the experimental method to set the steering system mode requirement for composite steering column support assembly of electrical vehicle (EV). One CAE model was used to analyze the steering system mode. Then two kinds of composite steering column support assembly were manufactured, and the NVH test was carried out. The steering system mode requirement was initially set according to the test result. The steering system mode test was conducted to verify the set mode requirement and $\mathrm{CAE}$ analysis result. Finally, the CAE model and the new set steering system mode were found appropriate for composite steering column support assembly of EV.

\section{Methodology}

For composite material, the damping value is much higher than that of steel, and the damping property would have much effect on NVH performance [26-32]. However, damping property is a reduction in the amplitude of an oscillation or vibration as a result of vibration energy being dissipated as other forms energy, including matrix damping, reinforced damping and material interface damping. Then, it is an important parameter for vibration control, noise reduction. Therefore, using high damping materials is an elegant way to reduce mechanical vibrations in mechanical engineering. Usually, the damping property of composite materials is much higher that of metal. Therefore, the stiffness of composite part can be lower that of the steel part, and the NVH performance requirement can be lower.

For steering column support assembly, the steering system mode is a crucial important parameter for $\mathrm{NVH}$ performance. Usually, the steering system mode would be defined before the steering column support assembly development so that the developed Steering column support assembly can satisfy NVH performance requirement. However, the damping property is extremely complex because of the different formation mechanism of its matrix damping, reinforced damping and material interface damping. Moreover, because of the complex shape of the composite component, the structural damping also plays an important role, the damping property is much more complex. So we can't evaluate the effect of damping property for the NVH performance of composite steering column support assembly directly for the reason that we can't test the damping property, and then the steering system mode requirement for composite steering column support assembly can't be defined.

Therefore, in this paper, an indirect method that is concurrent method (Figure 1) was used to study the effect of damping property for NVH performance of composite steering column support assembly. We can the reversed steps for this study. First of all, the steering system mode of the composite Steering column support assembly should be defined. Then, by comparing the defined steering system mode for the composite and steel component, the effect of damping property of composite material can be evaluated. The steering system mode was defined as follows, two kinds of composite components were manufactured: carbon fiber reinforced PA66 with good mechanical properties that can satisfy the $\mathrm{NVH}$ performance requirement and GF reinforced PA66 with much lower mechanical properties that can 't satisfy the requirement. Then, the NVH tests were concurrently conducted for the two kinds steering column support assembly. The steering system mode requirement of the composite component was defined by the vehicle dynamic testing of $\mathrm{NVH}$ tests for GF reinforced composite component, and was verified by the steering system test and vehicle dynamic testing of NVH tests of carbon fiber reinforced composite component. Finally, we can get the effect of damping property of the composite material on $\mathrm{NVH}$ performance of the composite steering column support assembly. 


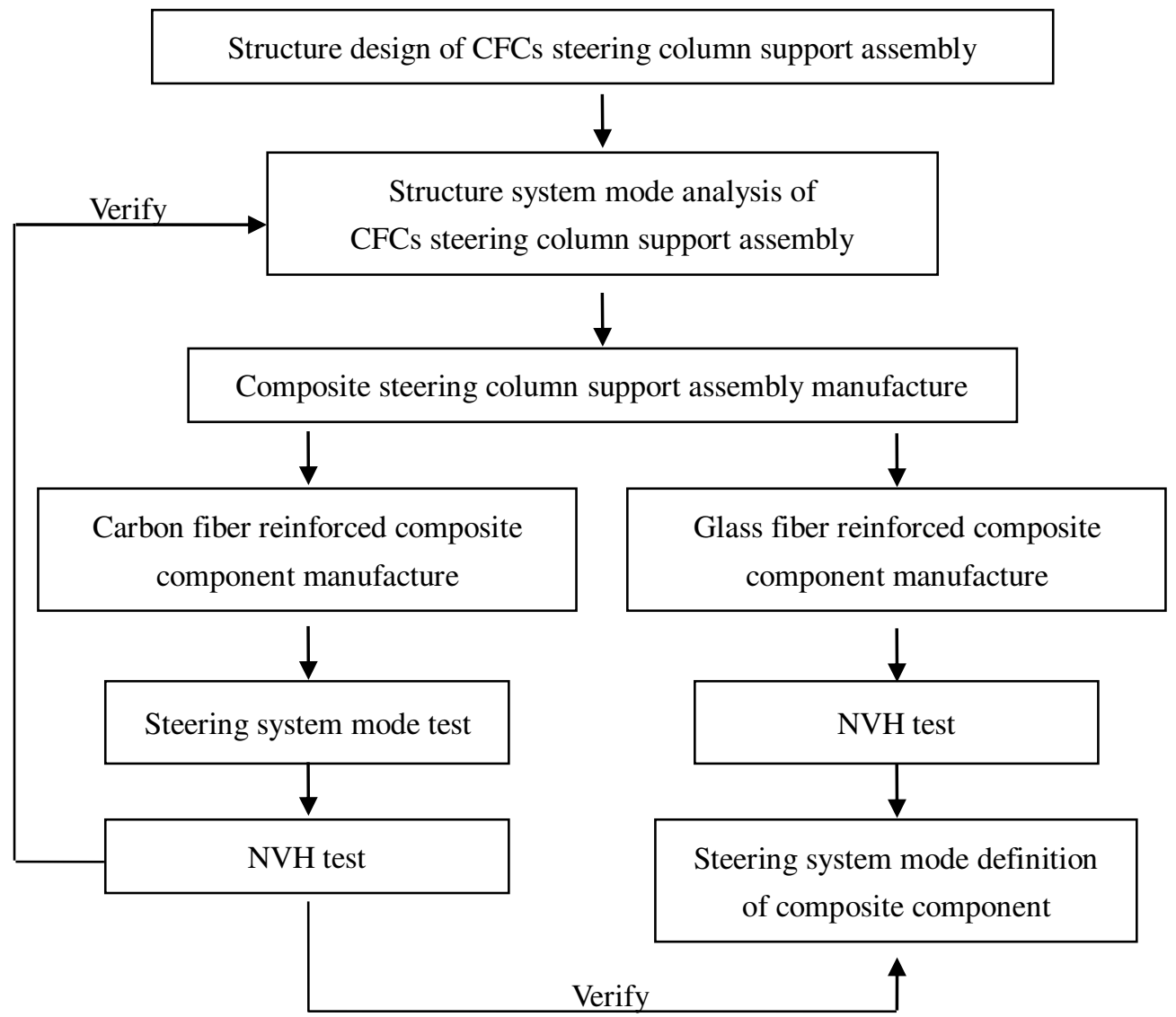

Figure 1. The concurrent test approach for composite Steering column support assembly

\section{Steering system mode analysis}

The detailed structure of composite steering column support assembly (Figure 2) was integrated into two parts: the steering column bracket assembly (the thickness is $4 \mathrm{~mm}$ ) and Steering column support assembly body (the thickness is $3.5 \mathrm{~mm}$ ).

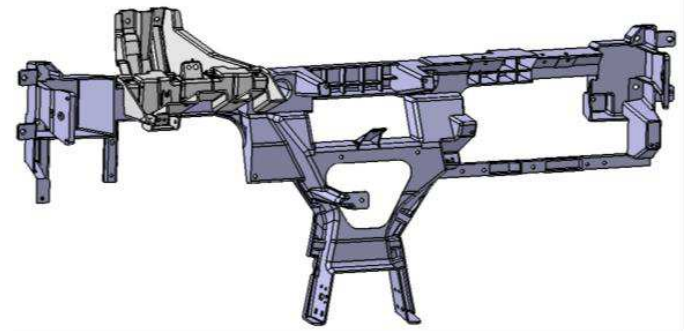

Figure 2. The detailed structure of the composite steering column support assembly

Because of the anisotropic material property of injection molding carbon fiber reinforced PA66 Steering column support assembly, the analysis method of steering mode analysis for this composite Steering column support assembly is definitely different from that of traditional metal Steering column support assembly. The used analysis method of the composite steering column support assembly is combined simulation. There are three steps for this method. The detail analysis process is as follows:

First of all, the carbon fiber direction of this composite part should be defined. Because carbon fiber flows along different directions during the moulding process of this composite part, the carbon fiber direction must be defined prior to the definition of material property. By mold flow analysis, the carbon fiber direction is defined as figure 3 .

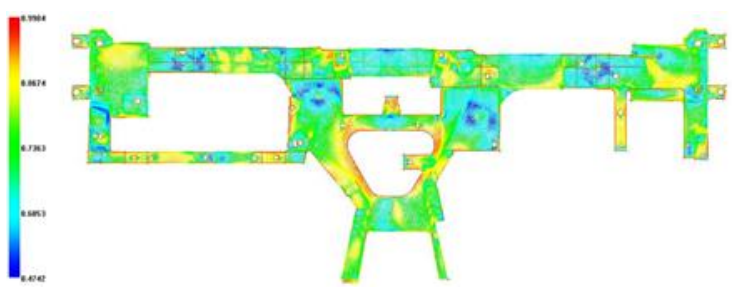

Figure 3. The carbon fiber direction of the component Secondly, the material document used for analysis was fitted by Digimat.

Thirdly, the steering system mode analysis(figure 4) was 
carried out by Abaqus. The used analysis model was shown as figure $4 \mathrm{a}$. The steering system was assembled to car body. Then the material document fitted from Digimat was imported to the model. The analysis result was shown in figure $4 \mathrm{~b}$ and table 1.

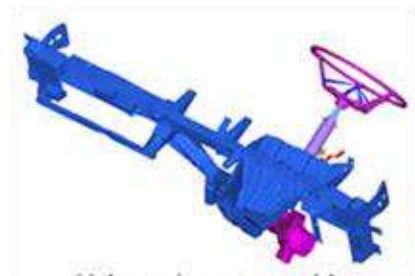

(a) the steering system model a. The steering system mode analysis model

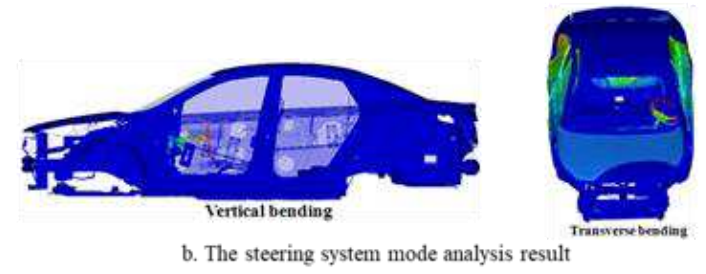

Figure 4. The steering system mode analysis

Table 1 The steering system mode analysis result

\begin{tabular}{|c|c|c|}
\hline Analysis mode & $\begin{array}{c}\text { Analysis } \\
\text { result }\end{array}$ & $\begin{array}{c}\text { Compared steel } \\
\text { part }\end{array}$ \\
\hline $\begin{array}{c}\text { First Order Vertical Vibration } \\
(\mathrm{Hz})\end{array}$ & 22.6 & 34 \\
\hline $\begin{array}{c}\text { First Order Transverse Vibration } \\
(\mathrm{Hz})\end{array}$ & 33.2 & 38 \\
\hline
\end{tabular}

Although the analysis result of composite Steering column support assembly is lower than that of steel part, the NVH performance of the composite Steering column support assembly may still meet the requirement. Compared with traditional metal alloy materials, the viscoelastic matrix of the fiber-reinforced composite material can effectively improve the damping performance of the structure while ensuring the load-bearing capacity of the structure. Relevant literature has confirmed that the damping of fiber-reinforced composite materials is tens to hundreds of times that of metal materials, it not only controls the vibration and noise of the structure, but also plays an important role in prolonging the service time of the structure under cyclic load and impact[33].

When the exciting factor disappears, the vibration will eventually stop slowly due to damping. Damping is one of the important factors that affect the dynamic response. When the disturbance frequency is close to the system's natural frequency, the damping has a great influence on the amplitude, resulting in a decrease in vibration. The logarithmic decline rate can characterize the attenuation of the amplitude. The higher the damping performance, the greater the value of logarithmic decline rate, the greater the amplitude attenuation (Figure 5).The mathematical formulation of logarithmic decline rate can be expressed as equation (1).

$$
\delta=\frac{1}{n} \ln \left(\frac{A_{i}}{A_{i+1}}\right)
$$

In which, $\delta$ is logarithmic decline rate, $\mathrm{n}$ is vibration cycles index, $\mathrm{A}$ is amplitude.

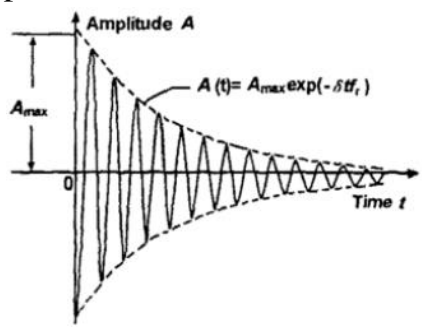

Figure 5. Displacement-time curve of damping vibration

\section{Manufacturing of composite Steering column support assembly}

By now, glass fibers and natural fibers are the most common fiber reinforced used in injection molding in the automotive industry. In order to make full use of the existing injection equipment as well as satisfy the performance requirement of Steering column support assembly, 30\% carbon fiber reinforced PA66 was used to manufacture the component. Only the screw needed to be done some changes.

For Steering column support assembly body, due to larger and more complex shape, the gates of main body mold (Figure 6a) were defined by mold flow analysis to control the deviations of the part with respect to the design structure. While, the gates of the steering column bracket mold (Figure 6b) were designed directly.

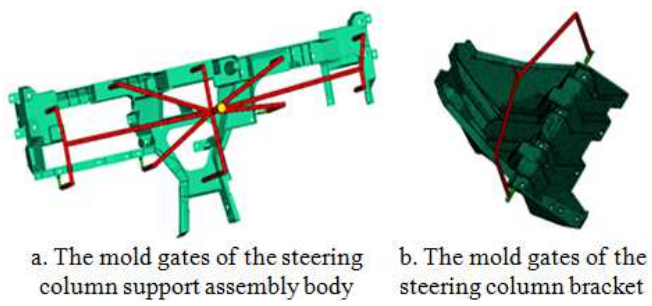

Figure 6. The mold gates of the Steering column support assembly

The detail manufacture process of CF reinforced PA66 Steering column support assembly was as follows: the raw plastic material was heated to remove absorbed water, and then was fed into the barrel. The barrel was heated to $300^{\circ} \mathrm{C}$ 
to melt the material. The mold was heated to $100^{\circ} \mathrm{C}$. The melted material was injected to the mold by the screw. The injection pressure in the barrel was divided into four sections as the screw moved forward, and then there were four different injection speeds, so that the material can be fulfilled all sections of the mold. The detail manufacturing parameters see table 2 . The manufactured prototype see figure $7 \mathrm{a}$. The weight of the two parts is $3.1 \mathrm{~kg}$ for the Steering column support assembly body and $1.4 \mathrm{~kg}$ for the steering column bracket.

Table 2. The manufacturing parameters of $\mathrm{CF}$ reinforcement PA66 Steering column support assembly

\begin{tabular}{|c|c|c|}
\hline $\begin{array}{c}\text { Manufacturing } \\
\text { factors }\end{array}$ & $\begin{array}{c}\text { Steering column } \\
\text { support assembly body }\end{array}$ & Steering column bracket \\
\hline $\begin{array}{c}\text { Injection } \\
\text { pressure(MPa) }\end{array}$ & $\begin{array}{l}\text { First section: } 95 . \\
\text { Second section: } 120 \text {. } \\
\text { Third section: } 100 . \\
\text { Fourth section: } 75\end{array}$ & $\begin{array}{c}\text { First section: } 70 \text {. Second } \\
\text { section: } 95 \text {. Third } \\
\text { section: } 90 . \text { Fourth } \\
\text { section: } 60\end{array}$ \\
\hline $\begin{array}{l}\text { Injection } \\
\operatorname{speed}(\mathrm{m} / \mathrm{s})\end{array}$ & $\begin{array}{l}\text { First section: } 85 \text {. } \\
\text { Second section: } 72 \text {. } \\
\text { Third section: } 70 \text {. } \\
\text { Fourth section: } 40\end{array}$ & $\begin{array}{c}\text { First section: } 65 \text {. Second } \\
\text { section: } 80 \text {. Third } \\
\text { section: } 75 \text {. Fourth } \\
\text { section: } 40\end{array}$ \\
\hline $\begin{array}{l}\text { Clamping force } \\
\text { (Tons) }\end{array}$ & 2500 & 720 \\
\hline $\begin{array}{l}\text { Holding pressure } \\
\text { (MPa) }\end{array}$ & 105 & 95 \\
\hline $\begin{array}{c}\text { Holding pressure } \\
\text { time }(\mathrm{s})\end{array}$ & 10 & 5 \\
\hline Cooling time(s) & 50 & 30 \\
\hline $\begin{array}{c}\text { Injection } \\
\text { temperature }\left({ }^{\circ} \mathrm{C}\right)\end{array}$ & 285 & 285 \\
\hline
\end{tabular}

In order to definite the steering system mode requirement, $40 \%$ GF reinforced PA66 with much lower mechanical properties (Table 3) than that of CF reinforced PA66 was chose to manufacture Steering column support assembly. Because of the same matrix, the manufacturing process for the GF reinforcement PA66 Steering column support assembly is similar to that of CF reinforcement PA66 Steering column support assembly (Table 4). The temperature for the barrel and mold is the same as that of CF reinforcement PA66 Steering column support assembly. Only the manufacturing parameters have a little difference. The manufacturing parameters see table 2. The manufactured prototype is shown as figure $7 \mathrm{~b}$. The weight of the two parts is $3.3 \mathrm{~kg}$ for the Steering column support assembly body and $1.5 \mathrm{~kg}$ for the steering column bracket.

Table 3. Mechanical property of composite materials

\begin{tabular}{cccccc}
\hline $\begin{array}{c}\text { Composite } \\
\text { Material }\end{array}$ & $\begin{array}{c}\text { Densit } \\
\mathrm{y} \\
\left(\mathrm{g} / \mathrm{cm}^{3}\right)\end{array}$ & $\begin{array}{c}\text { Tensile } \\
\text { Strength } \\
(\mathrm{Mpa})\end{array}$ & $\begin{array}{c}\text { Tensile } \\
\text { Modulus } \\
(\mathrm{Gpa})\end{array}$ & $\begin{array}{c}\text { Flexural } \\
\text { strength } \\
(\mathrm{Mpa})\end{array}$ & $\begin{array}{c}\text { Flexural } \\
\text { modulu } \\
\mathrm{s}(\mathrm{Gpa})\end{array}$ \\
\hline $\begin{array}{c}\text { PA66-30\% } \\
\mathrm{CF}\end{array}$ & 1.32 & 323 & 32.8 & 506 & 30.8 \\
$\begin{array}{c}\text { PA66-40\% } \\
\text { LGF }\end{array}$ & 1.22 & 230 & 17 & 320 & 14 \\
\hline
\end{tabular}

Table 4. The manufacturing parameters of GF reinforcement PA66 Steering column support assembly

\begin{tabular}{|c|c|c|}
\hline $\begin{array}{l}\text { Manufacturing } \\
\text { factors }\end{array}$ & $\begin{array}{l}\text { Steering column support } \\
\text { assembly body }\end{array}$ & $\begin{array}{c}\text { Steering column } \\
\text { bracket }\end{array}$ \\
\hline $\begin{array}{c}\text { Injection } \\
\text { pressure(MPa) }\end{array}$ & $\begin{array}{c}\text { First section: } 90 . \text { Second } \\
\text { section: } 120 . \text { Third } \\
\text { section: } 100 . \text { Fourth } \\
\text { section: } 70\end{array}$ & $\begin{array}{l}\text { First section: } 85 . \\
\text { Second section: } 95 \text {. } \\
\text { Third section: } 80 \text {. } \\
\text { Fourth section: } 60\end{array}$ \\
\hline $\begin{array}{c}\text { Injection } \\
\operatorname{speed}(\mathrm{m} / \mathrm{s})\end{array}$ & $\begin{array}{c}\text { First section: } 80 \text {. Second } \\
\text { section: } 60 \text {. Third } \\
\text { section: } 60 . \text { Fourth } \\
\text { section: } 40\end{array}$ & $\begin{array}{l}\text { First section: } 70 \text {. } \\
\text { Second section: } 80 \text {. } \\
\text { Third section: } 60 \text {. } \\
\text { Fourth section: } 50\end{array}$ \\
\hline $\begin{array}{l}\text { Clamping force } \\
\text { (Tons) }\end{array}$ & 2500 & 720 \\
\hline $\begin{array}{l}\text { Holding pressure } \\
\qquad(\mathrm{MPa})\end{array}$ & 105 & 95 \\
\hline $\begin{array}{c}\text { Holding pressure } \\
\text { time }(\mathrm{s})\end{array}$ & 10 & 5 \\
\hline Cooling time(s) & 50 & 30 \\
\hline $\begin{array}{c}\text { Injection } \\
\text { temperature }\left({ }^{\circ} \mathrm{C}\right)\end{array}$ & 270 & 270 \\
\hline
\end{tabular}

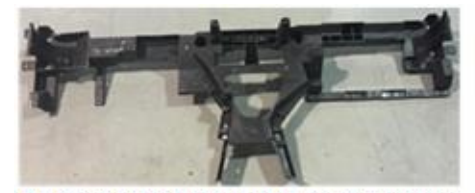

(a) The CFreinforcedPA66 steering columm support assembly body

a. The CFreinforcedPA66 steering columnsupport assembly

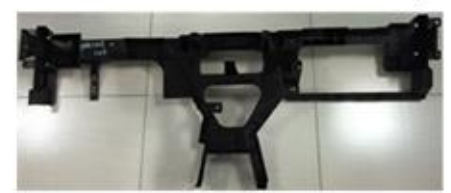

(a) The GFreinforced PA66 steering column support assembly body

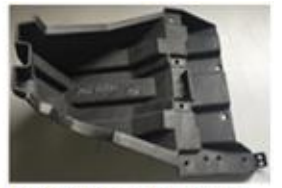

(b) The steering column bracket

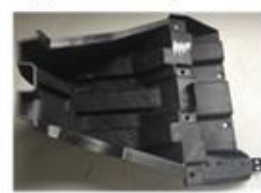

(b) The steering column bracket b. The GFreinforced PA66 steering column support assembly

Figure 7. The composite steering column support assembly

\section{Tests}

By now, the damping value of this composite material component can't be test directly, as component size, material composition, material construction and so on would affect it. So we can't evaluate the effect of the damping property for this component directly. Then, by an indirect method that is comparing the steering system mode requirement of the composite component with that of the steel component, we can evaluate the effect of damping property.

Therefore, definition of the steering system mode requirement of the composite component is crucial. By the following test the steering system mode requirement was defined.

\subsection{Steering system mode test}


The steering system mode of CFRP Steering column support assembly should be tested and the mode analysis result should be verified to be reasonable. Therefore, the steering system mode test was performed. The test was carried out as follows: the CF reinforced PA66 Steering column support assembly was assembled to the car. Then four signal sensors were fixed on the four points of steering wheel showing in figure 8 . The steering wheel was knocked by hammer. The resonance frequency was defined by the vibration signal sensed by the sensors, and the steering system mode was tested.

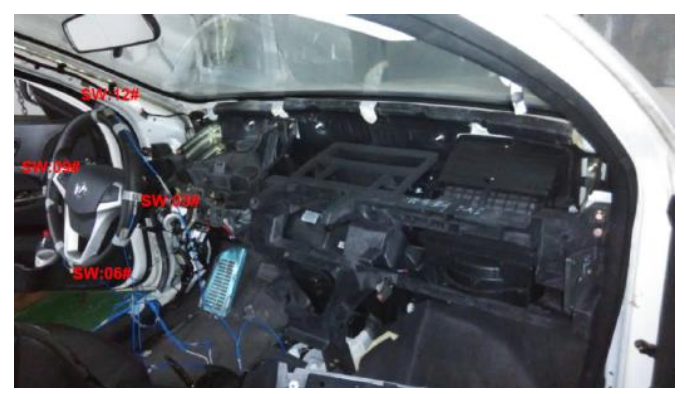

Figure 8. The steering system mode test

By comparing the analysis result and the test result (Table 5), the first order vertical bending frequency is same for the two results, and the first order transverse frequency for the analysis result is higher than that of the test result for $2.5 \mathrm{~Hz}$ which can satisfy the error requirement between the analysis result and the test result. Therefore, the analysis result can be good agreement with the test result for the steering system mode of the composite Steering column support assembly.

Table 5. The steering system mode test result

\begin{tabular}{ccc}
\hline Vibration Mode & Test Result & Analysis Result \\
\hline $\begin{array}{c}\text { First Order Vertical bending }(\mathrm{Hz}) \\
\text { First Order Transverse bending } \\
(\mathrm{Hz})\end{array}$ & 22.6 & 22.6 \\
\hline
\end{tabular}

\section{$5.2 \quad$ NVH test}

In order to verify whether the CFRP Steering column support assembly with the steering system mode that is lower than that of steel part can satisfy the NVH requirement, NVH test under various conditions was conducted. The NVH test result shows that the noise (Figure 10 and Table 6) and vibration (Figure 11) performance of the test vehicle with the composite part is closed to that of the compared vehicle assembled with steel component. The NVH performance of CF reinforced PA66 Steering column support assembly can fulfil the requirement.

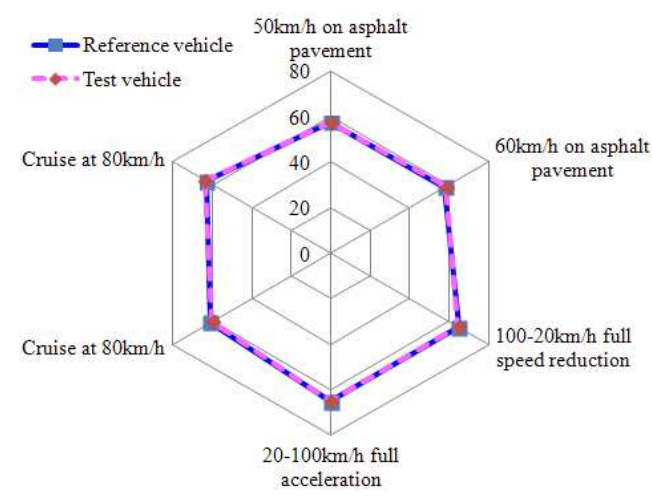

Figure 10. Interior noise test of CFRP Steering column support assembly[17]

Table 6. Interior noise test of CFRP Steering column support assembly [17]

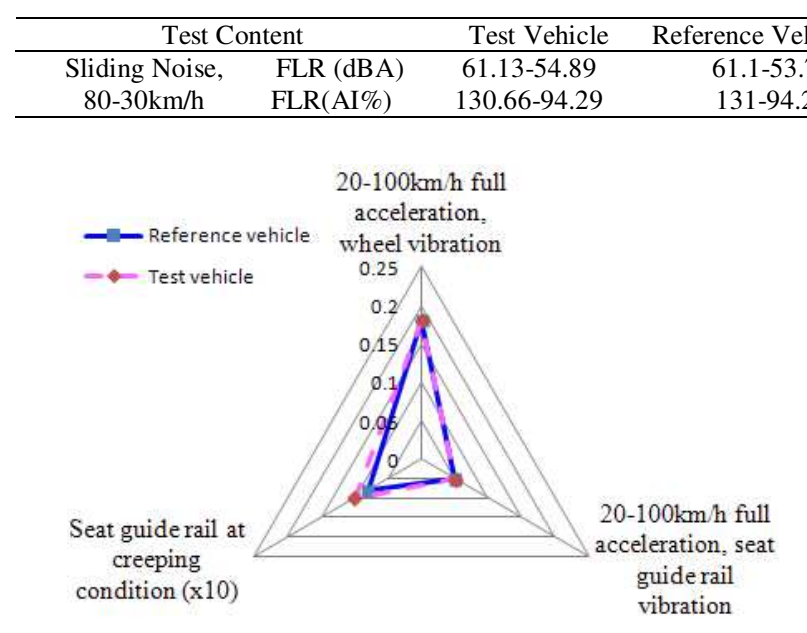

Figure 11. Vibration test of CFRP Steering column support assembly [17]

Although CFRP Steering column support assembly can satisfy NVH requirement, the steering system mode requirement can't be set. In order to determine the mode requirement, the resonance frequency of the composite steering column support system assembly must be measured. So the NVH test for glass fiber reinforced PA66 steering column support system assembly was conducted, as this part with much lower mechanical property would not pass the NVH test and the steering wheel would have resonance vibration under some frequency. The test result shows that the glass fiber composite Steering column support assembly can satisfy the noise requirement (Figure 12 and Table 7). For vibration result (Figure 13), only the 
steering wheel vibration acceleration which is $0.45 \mathrm{~g}$ is much higher than that of compared steel part, and can't meet the requirement. At the speed of $47 \mathrm{~km} / \mathrm{h}$, the steering wheel have obvious vibration along $\mathrm{X}$ and $\mathrm{Y}$ direction, and the resonance frequency is $19 \mathrm{~Hz}$ (Figure 14a). The steering wheel also has obvious vibration at $66 \mathrm{~km} / \mathrm{h}$ and $100 \mathrm{~km} / \mathrm{h}$ along $\mathrm{Z}$ direction, and the resonance frequency is $27 \mathrm{~Hz}$ (Figure 14b).

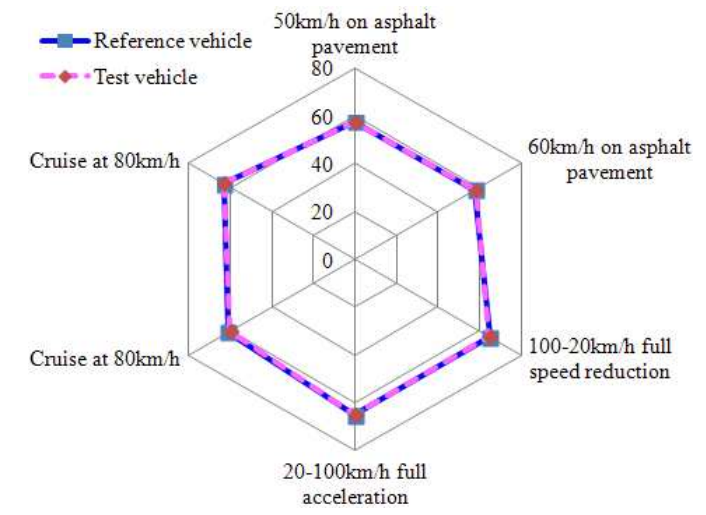

Figure 12. Interior noise test of GFC Steering column support assembly

Table 7. Interior noise test of GFC Steering column support assembly

\begin{tabular}{cccc}
\hline \multicolumn{2}{c}{ Test Content } & Test Vehicle & Reference Vehicle \\
\hline Sliding Noise & FLR (dBA) & $60.8-53.5$ & $61.1-53.7$ \\
80-30km/h & FLR (AI\%) & $133.6-96.5$ & $131-94.2$ \\
\hline
\end{tabular}

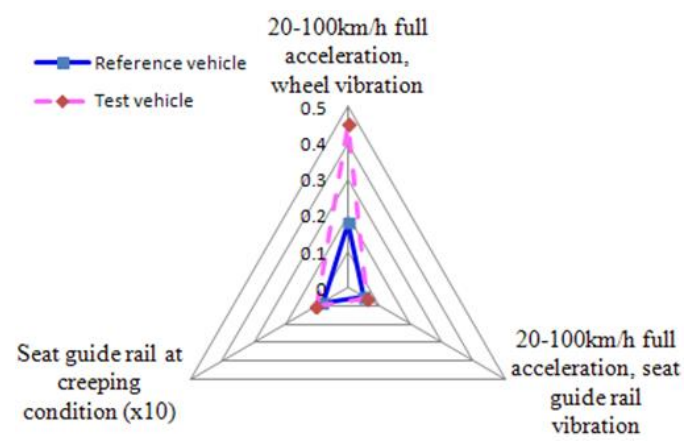

Figure 13. Vibration test of GFC Steering column support assembly

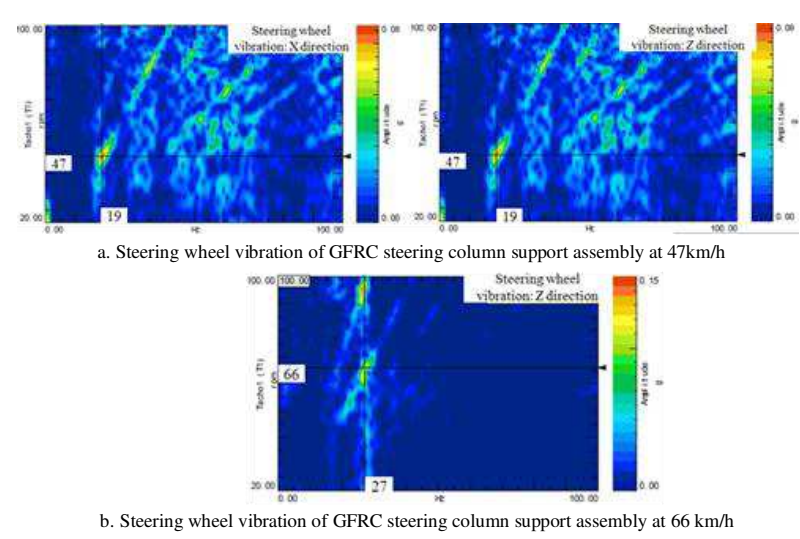

Figure 14. Steering wheel vibration of GFC Steering column support assembly

\section{Results and discussion}

According to the resonance vibration frequency of glass fiber composite Steering column support assembly and the rule that the first natural frequency should keep more than $3 \mathrm{~Hz}$ away from the resonance frequency, the steering system mode for composite Steering column support assembly of the EV is defined as follows: the first order vertical bending frequency should be higher than $22 \mathrm{~Hz}$, the first order transverse bending frequency should be higher than $30 \mathrm{~Hz}$. By comparing the defined steering system mode requirement and the steering system mode test result of CF reinforced PA66 Steering column support assembly (Table 8), we can see that the test result of the first order vertical bending mode is only higher for $0.6 \mathrm{~Hz}$ than the defined requirement, and the difference for the first order transverse bending mode between the test result and the requirement is only $0.7 \mathrm{~Hz}$. In a word, the difference between the test result of the CFRP component that can satisfy the NVH performance requirement and the defined requirement is small, and we can conclude that the steering system mode requirement for this kind of composite Steering column support assembly is reasonable.

Table 8. The comparison of the definition and the test result

\begin{tabular}{ccc}
\hline Vibration Mode & $\begin{array}{c}\text { Steering system mode } \\
\text { requirement definition }\end{array}$ & $\begin{array}{c}\text { Test } \\
\text { result }\end{array}$ \\
\hline First Order Vertical bending & 22 & 22.6 \\
$\begin{array}{c}(\mathrm{Hz}) \\
\text { First Order Transverse bending } \\
(\mathrm{Hz})\end{array}$ & 30 & 30.7 \\
\hline
\end{tabular}

Then by comparing the steering system mode requirement for the composite Steering column support assembly with that of the steel part (Table 9), the value of the first order vertical bending mode of the composite Steering column support assembly is lower than that of the steel component 
for $12 \mathrm{~Hz}$ which counts for $35.3 \%$ percent of the requirement for the steel component, and for the first order transverse bending mode, the requirement of the composite Steering column support assembly is lower for $8 \mathrm{~Hz}(21.1 \%$ of the requirement of the steel component) than that of the steel Steering column support assembly (Figure 15). By this comparison, we can conclude that the damping property of composite material have above $21 \%$ percent effect on the NVH performance of composite component, and for the crucial bending mode, the effect is much higher, that is above $35 \%$ percent.

Table 9. The comparison of the steering system mode definition

\begin{tabular}{ccc} 
Table 9. The comparison of the steering system mode definition \\
\hline Vibration Mode & $\begin{array}{c}\text { Steering system } \\
\text { mode requirement } \\
\text { definition }\end{array}$ & $\begin{array}{c}\text { Steering system } \\
\text { mode requirement } \\
\text { of steel part }\end{array}$ \\
\hline $\begin{array}{c}\text { First Order Vertical } \\
\text { bending (Hz) }\end{array}$ & 22 & 34 \\
$\begin{array}{c}\text { First Order Transverse } \\
\text { bending (Hz) }\end{array}$ & 30 & 38 \\
\hline
\end{tabular}

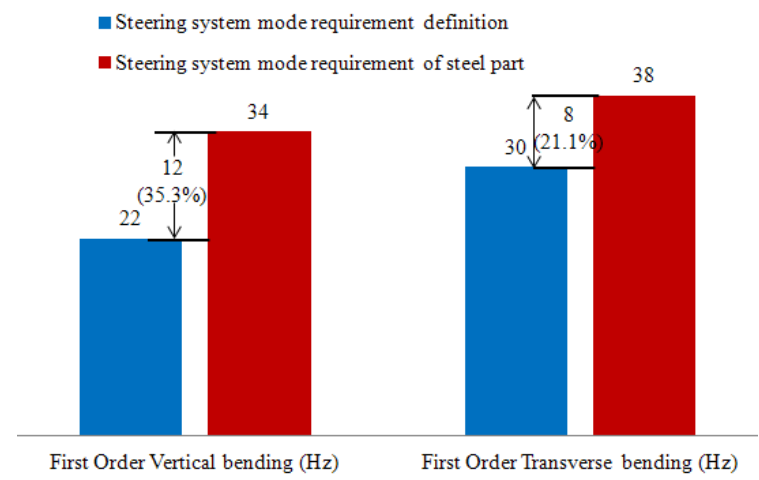

Figure 15. The comparison of the steering system mode definition

\section{Conclusions}

We studied the steering system mode definition of composite Steering column support assembly with a simple method. Due to the damping property of composite materials, the composite component with a significantly lower first natural frequency compared to metal component can be accepted with an equivalent or better $\mathrm{NVH}$ performance. However, it is very hard to test the damping value of composite component. Therefore, a simple method that is concurrent test approach was used to definite the steering system mode of composite Steering column support assembly. In the manufacturing step of the method, two kinds of composite that are $\mathrm{CF}$ reinforced PA66 Steering column support assembly and glass fiber reinforced PA66 Steering column support assembly were manufactured. The tests were concurrent conducted for the two kind parts. By the NVH test of glass fiber composite Steering column support assembly which would not satisfy the NVH performance requirement, we could get the resonance vibration frequency of steering wheel, and then the steering system mode of composite Steering column support assembly of EV was defined. Then by the steering system mode test and NVH test of CFRP Steering column support assembly which would satisfy the NVH performance requirement, the steering system mode analysis and the steering system mode requirement were verified. By comparing the steering system mode requirement, we can conclude that the damping property of this composite material have over $21 \%$ percent effect on the NVH performance of the composite Steering column support assembly.

\section{Declaration}

\section{Acknowledgements}

The authors sincerely thanks to Professor senior engineer Bo Liu and Professor Jin-yan Wang of Dalian University of Technology for his critical discussion and reading during manuscript preparation.

\section{Funding}

Supported by National Key Research and Development Program of China (Grant No. 2016YFB0101703, 2016YFB0101600, 2016YFB0101601), Chongqing Innovation Key R \& D Projects of Common Key Technology of Key Industries (Grant No. cstc2018jszx-cyzdX0138), Chongqing Technological Innovation and Application Development Project (Grant No. cstc2018jscx-msybX0008), and Public Service Platform for the Industrialization of Technological Innovation Achievements in the Field of Robot and Intelligent Manufacturing in Chongqing (Grant Nos. 2019-00900-1-1)

\section{Availability of data and materials}

The datasets supporting the conclusions of this article are included within the article.

\section{Authors' contributions}

The author' contributions are as follows: Bo Liu, Jin-yan Wang and Ming-de Ding was in charge of the whole trial; Ming-de Ding wrote the manuscript; Zhen-hua Fan, Fu-qiang Zhai and $\mathrm{Lu} \mathrm{Li}$ assisted with sampling and laboratory analyses. 


\section{Competing interests}

The authors declare no competing financial interests.

\section{Consent for publication}

Not applicable

\section{Ethics approval and consent to participate}

Not applicable

\section{References}

[1] Winkler, S.L., Wallington, T.J., Maas, H. \& Hass, H. Light-duty vehicle $\mathrm{CO} 2$ targets consistent with $450 \mathrm{ppm} \mathrm{CO} 2$ stabilization. Environ. Sci. Technol., 2014, 48, 6453-6460.

[2] Kawajari,K., Kobayashi,M., Sakamoto,K. Lightweight materials equal lightweight greenhouse gas emissions? A historical analysis of greenhouse gases of vehicle material substitution. J. Clean. Prod., 2020, 253, 119805 .

[3] Pervaiz, M, Panthapulakkal, S, Birat, KC et al. Emerging trends in automotive lightweighting through novel composite materials. Mater Sci Appl., 2016, 7(01): 26.

[4] Sahu, P, Gupta, MK. Sisal (Agave sisalana) fiber and its polymer-based composites: a review on current developments. $J$ Reinf Plast Compos., 2017, 36(24): 1759-1780.

[5] Mingde Ding, Cong Gao, Bo Liu, et al. Study of the effect of load distribution on SMC engine room bracket of electric vehicle. IJVD, 2019, 79(2-3).

[6] Pickering, KL, Efendy, MA, Le, TM. A review of recent developments in natural fibre composites and their mechanical performance. Compos Part A Appl Sci Manuf., 2016, 83: 98-112.

[7] Annandarajah, C., Langhorst, A., Kiziltas, A., Grewell, D., Mielewski, D., Montazami, R.. Hybrid cellulose-glass fiber composites for automotive applications. Materials, 2019, 12, 3189.

[8] Mathijsen, D. Long fiber thermoplastics are a key technology in expanding existing markets for composites. Reinforced Plastics, 2019, 63(5): 267-272.

[9] Paolo, F., Attilio, M., Andrea, B.. Advanced composites for the body and chassis of a production high performance car. IJVD, 2007, 44(3/4): 233-246.

[10] İsmail Durgun. A comparative study on the mechanical properties of carbon and glass fibre-reinforced epoxy, polyester and vinyl ester-based composites. IJVD, 2016, 71(1-4): 358-363.

[11] Alsaadi, A., Shi, Y., Pan, L. et al. Vibration energy harvesting of multifunctional carbon fibre composite laminate structures. Composites Science and Technology, 2019, 178: 1-10.

[12] Zhang SD, Gao L, Han JC, Li ZX, Zu GQ, Ran X, Sun YG. Through-thickness thermal conductivity enhancement and tensile response of carbon fiber-reinforced polymer composites. Compos Part B Eng., 2019, 165:183-192.

[13] Forintos N, Czigany T. () 'Multifunctional application of carbon fiber reinforced polymer composites: electrical properties of the reinforcing carbon fibers-a short review', Compos Part B Eng., 2019, 162:331-343.

[14] K. Shanmugam, V. Gadhamshetty, P. Yadav, D. Athanassiadis, M. Tysklind, V.K. K. Upadhyayula, Advanced high strength steel and carbon fiber reinforced polymer composite body in white for passenger cars: environmental performance and sustainable return on investment under different propulsion modes. Sustain. Chem.
Eng., 2019, 7 (5): 4951-4963.

[15] Choi, Y., Lee, J., Panicker, S. S.. Mechanical properties, springback, and formability of W-temper and peak aged 7075 aluminum alloy sheets: Experiments and modeling. International Journal of Mechanical Sciences, 2020, 170.

[16] Fashami, H. A. A., Arab, N. B. M., Gollo, M. H.. The Effect of Rapid Deformation Process to Improve Creep and Tensile Resistance of AZ91 Magnesium Alloy Plates. International Journal of Engineering, 2020, 33(10): 2039-2046.

[17] Ding MD, Liu JC, Su JB, Su Z, Liu B. On the Development of Lightweight IP Carrier. SAE international 2017, 2017, Paper No. 2017-01-0502.

[18] Tharumarajah, A., Koltun, P.. Improving environmental performance of magnesium instrument panels. Resources Conservation And Recycling, 2016, 54(12): 1189-1195.

[19] Pitrof, S., R. Merrifield. Engineering Development of a Composite Cross Car Beam. SAE international 1997, 1997, Paper No. 970727

[20] Jahn, Thomas and Ivan Baudouin. Development of Lightweight, Modular Hybrid-Material Cockpit Structures for Passenger Vehicles. SAE World Congress 2005, 2005, Paper No. 2005-01-1220

[21] Chandra R, Singh S, Gupta K. Damping studies in fiber-reinforced composites-a review. Compos Struct., 1999, 46:41-51.

[22] Rajak, D. K., Pagar, D. D., Menezes, P. L.. Fiber-Reinforced Polymer Composites: Manufacturing, Properties, and Applications. Polymers, 2019, 11(10).

[23] Chandra R, Singh S, Gupta K. A study of damping in fiber-reinforced composites. J Sound Vib, 2003, 262(3):475-96.

[24] Li J, Narita Y. Analysis and optimal design for the damping property of laminated viscoelastic plates under general edge conditions. Compos Part B: Eng., 2013, 45(1):972-80.

[25] Treviso, A., Genechten, V.B., Mundo, D. Damping in composite materials: Properties and models. Compos Part B: Eng., 2015, 78:144-152.

[26] Li, Y, Cai, S, Huang, X. Multi-scaled enhancement of damping property for carbon fiber reinforced composites. Compos Sci Technol., 2017, 143: 89-97.

[27] Ding, GP, Lu, ZY, Dai, ZL. Vibration Characteristics Analysis and Experimental Study of Carbon-Fiber Reinforced Plastic-Metal Hybrid Drive Shaft. Science of Advanced Materials, 2020, 12(10): 1457-1464.

[28] Groo, L. A., Steinke, K., Inman, D. J. et al. Vibration Damping Mechanism of Fiber-Reinforced Composites with Integrated Piezoelectric Nanowires. Acs Applied Materials \& Interfaces, 2019, 11(50): 47373-47381 .

[29] Wu, J.; Mizuno, Y.; Nakamura, K. Enhancement in Mechanical Quality Factors of Poly Phenylene Sulfide under High-Amplitude Ultrasonic Vibration through Thermal Annealing. Ultrasonics, 2019, $91,52-61$.

[30] Li H., Xue P., Guan Z., et al. A new nonlinear vibration model of fiber-reinforced composite thin plate with amplitude-dependent property. Nonlinear Dyn., 2018, 94: 2219-2241

[31] Lim, J., Kim, Sang-W. Enhanced damping characteristics of carbon fiber reinforced polymer-based shear thickening fluid hybrid composite structures. Journal of Intelligent Material Systems and Structures, 2020, 31(20): 2291-2303 .

[32] Bhudolia, KS, Perrotey, P, Joshi, SC. Enhanced vibration damping and dynamic mechanical characteristics of composites with novel pseudo-thermoset matrix system. Compos Struct., 2017, 179: 502-513.

[33] Chandra R, Singh S P, Gupta K. Damping studies in fiber-reinforced 
composites-a review. Compos Struct., 1999, 46(1): 41-51.

\section{Biographical notes}

Ming-De Ding, born in 1986, is currently a senior engineer at Chongqing University of Arts and Sciences and a PhD candidate at Dalian University of Technology, China. He received his master degree from Shandong University, China, in 2012. His research interests include composite materials and vehicle lightweight.

Tel: 13350322194; E-mail: 987096806@qq.com

Bo Liu, born in 1977, is currently a professor senior engineer at Chongqing Changan Automobile Co Ltd, China. He won the National Plan for Talented Persons of Ten Thousand Talents and the National outstanding scientific and technical workers, and received his PhD degree from Jilin University, China, in 2007.

E-mail: 150414213@qq.com

Zhen-Hua Fan, born in 1983, is currently a senior engineer at Chongqing Polycomp International Corp, China.

Jin-yan Wang, born in 1970, is currently a professor and a PhD candidate supervisor at Department of Polymer Science \& Materials, College of Chemical, China, won the National Plan for Talented Persons of Ten Thousand Talents. Her main research interests include high-performance resins and their composites, functional coatings, adhesives, and $3 \mathrm{D}$ printing materials that can withstand temperatures above $300^{\circ} \mathrm{C}$.

E-mail: wangjinyan@dlut.edu.cn
Fu-Qiang Zhai, born in 1985, is currently an associate research fellow at Chongqing University of Arts and Sciences, China. He received his $\mathrm{PhD}$ degree from Polytechnic University of Catalonia, Spanish, in 2015.

Lu Li, born in 1982, is currently a professor, the deputy director of Research Institute for New Materials Technology and the full-time deputy director of Co-innovation Center for Micro/Nano Optoelectronic Materials and Devices of Chongqing University of Arts and Sciences, China. He received his $\mathrm{PhD}$ degree from University of Electronic Science and Technology, was the post-doctor and the Researcher of University of California-Los Angeles. His research interests include optoelectronic materials and devices for displaying and lighting and those energy conversion devices, and the development and application of nanocomposite materials.

\section{Appendix}

Appendix and supplement both mean material added at the end of a book. An appendix gives useful additional information, but even without it the rest of the book is complete: In the appendix are forty detailed charts. A supplement, bound in the book or published separately, is given for comparison, as an enhancement, to provide corrections, to present later information, and the like: A yearly supplement is issue. 


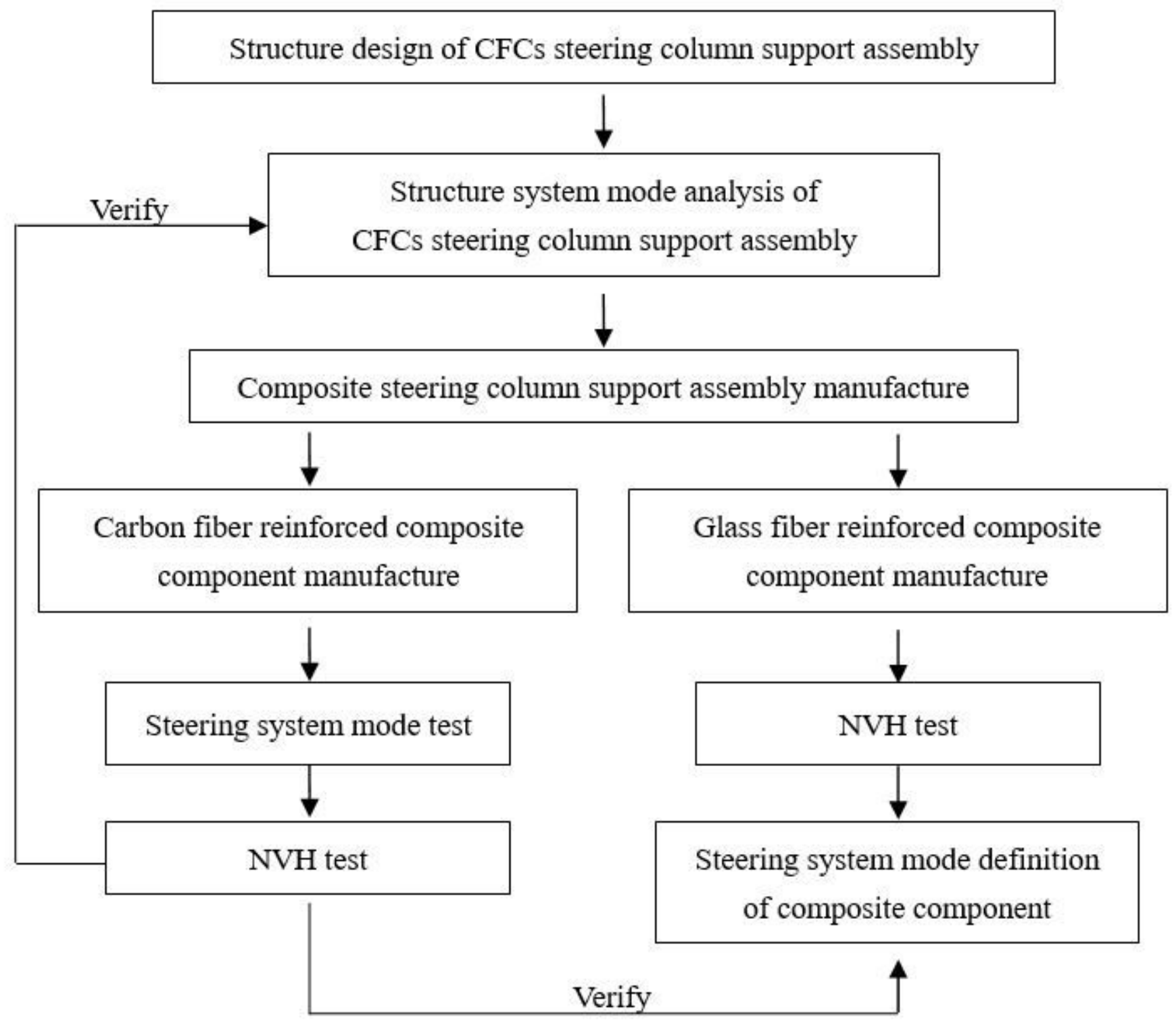

Figure 1

The concurrent test approach for composite Steering column support assembly 


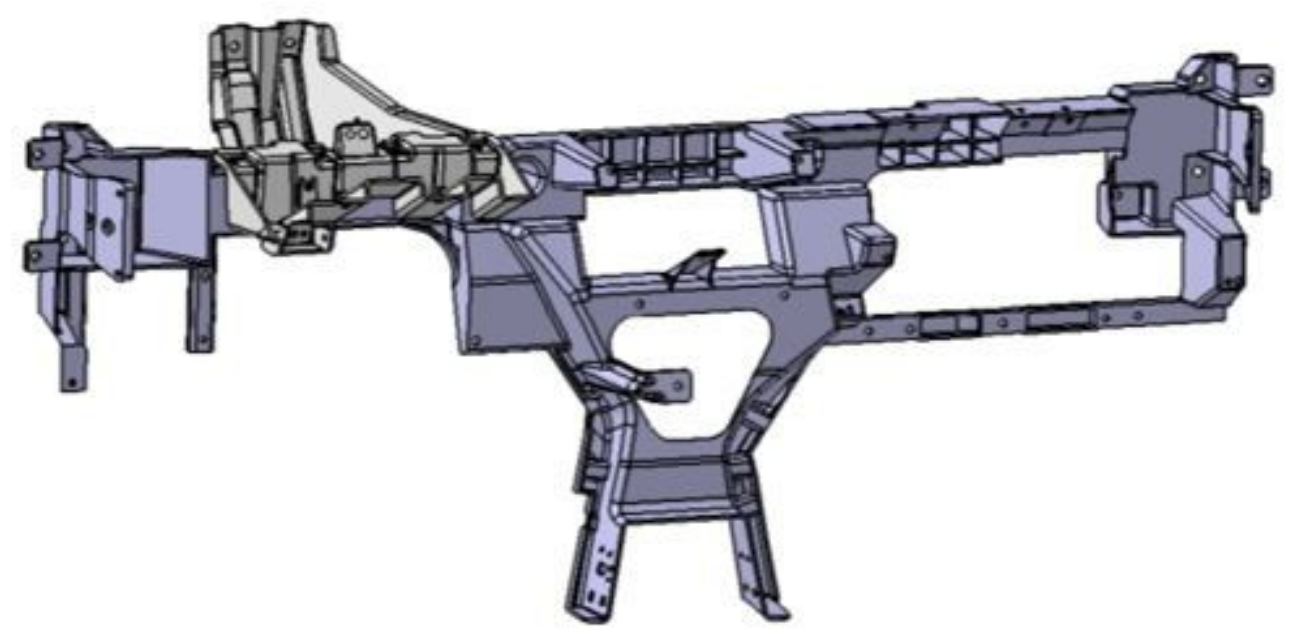

Figure 2

The detailed structure of the composite steering column support assembly

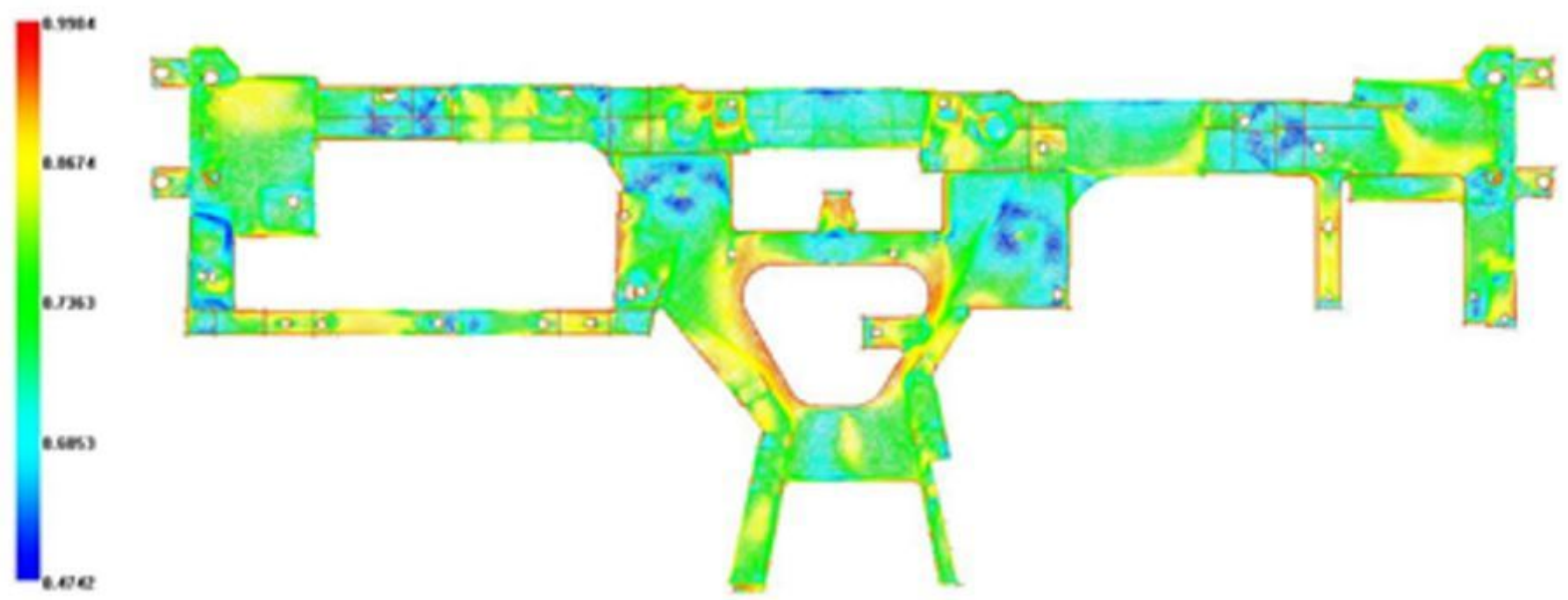

Figure 3

The carbon fiber direction of the component 


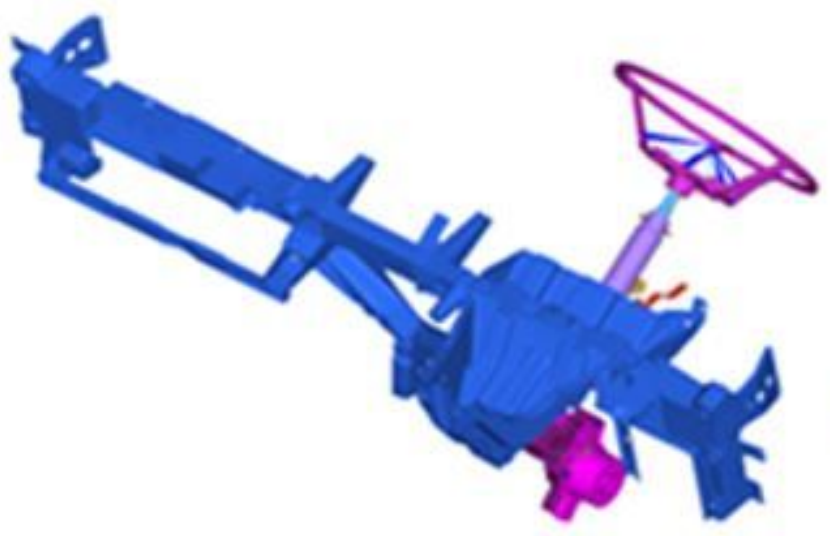

(a) the steering system mode1

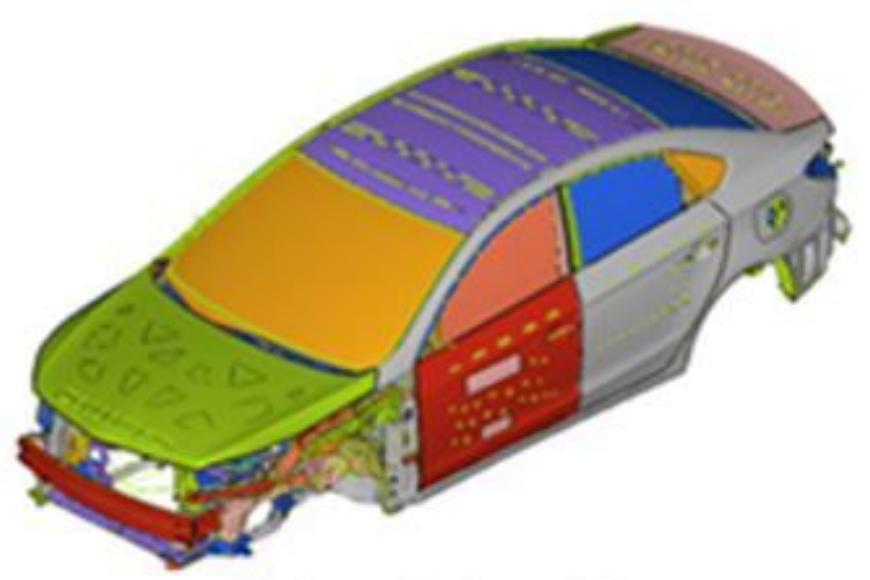

(b) the carbody model

a. The steering system mode analysis model
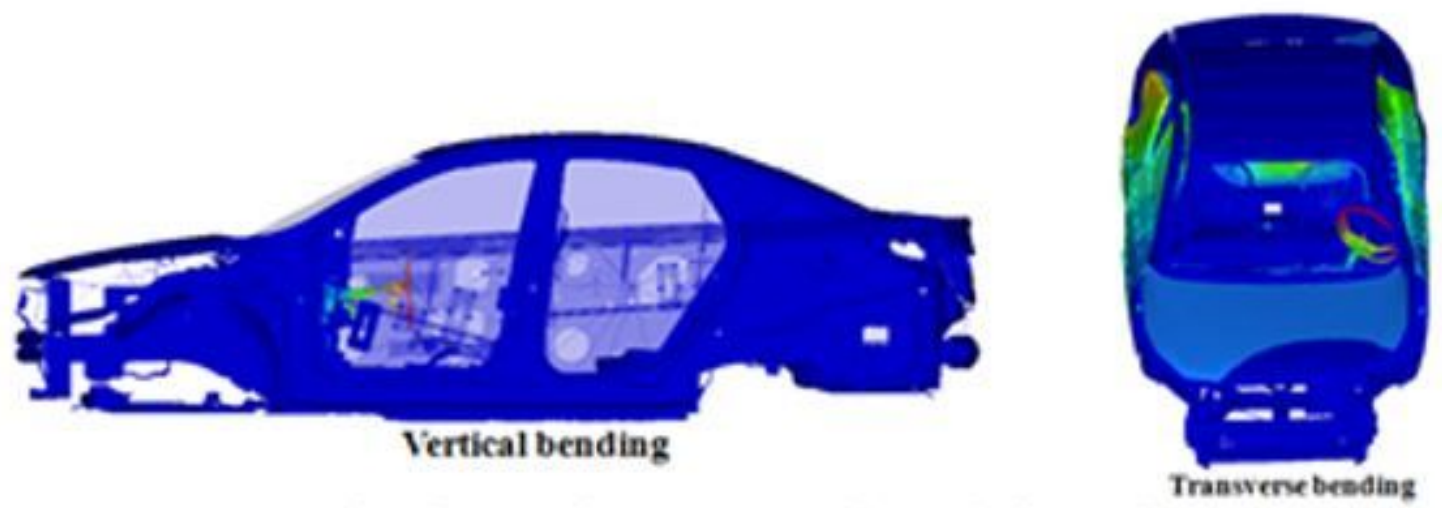

b. The steering system mode analysis result

Figure 4

The steering system mode analysis

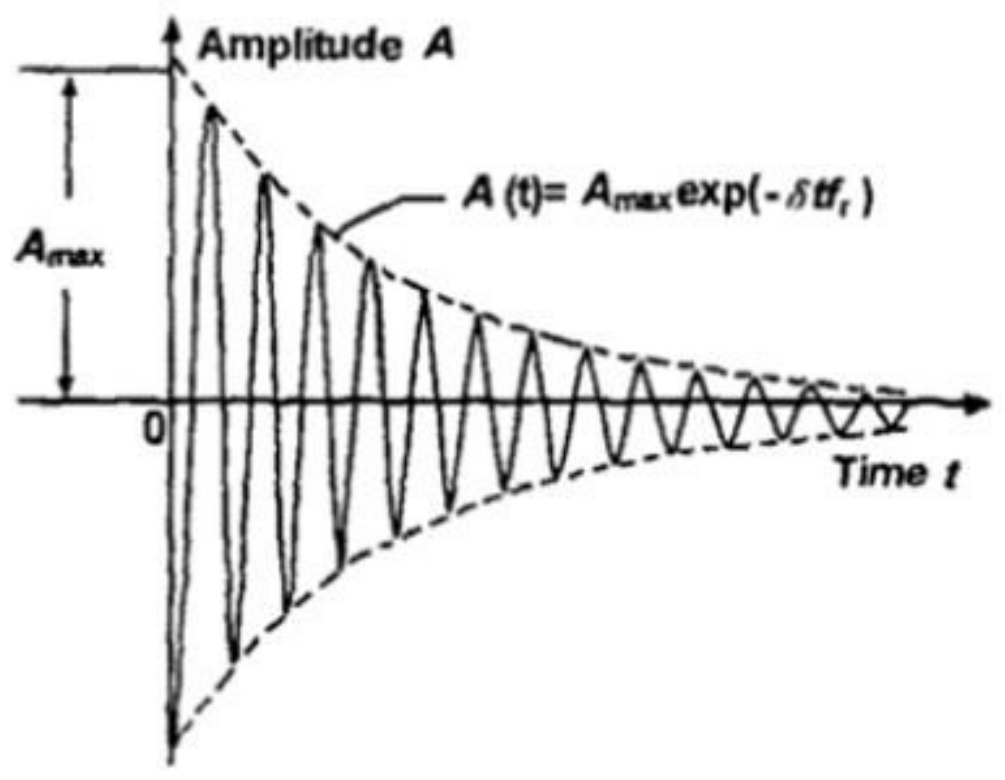



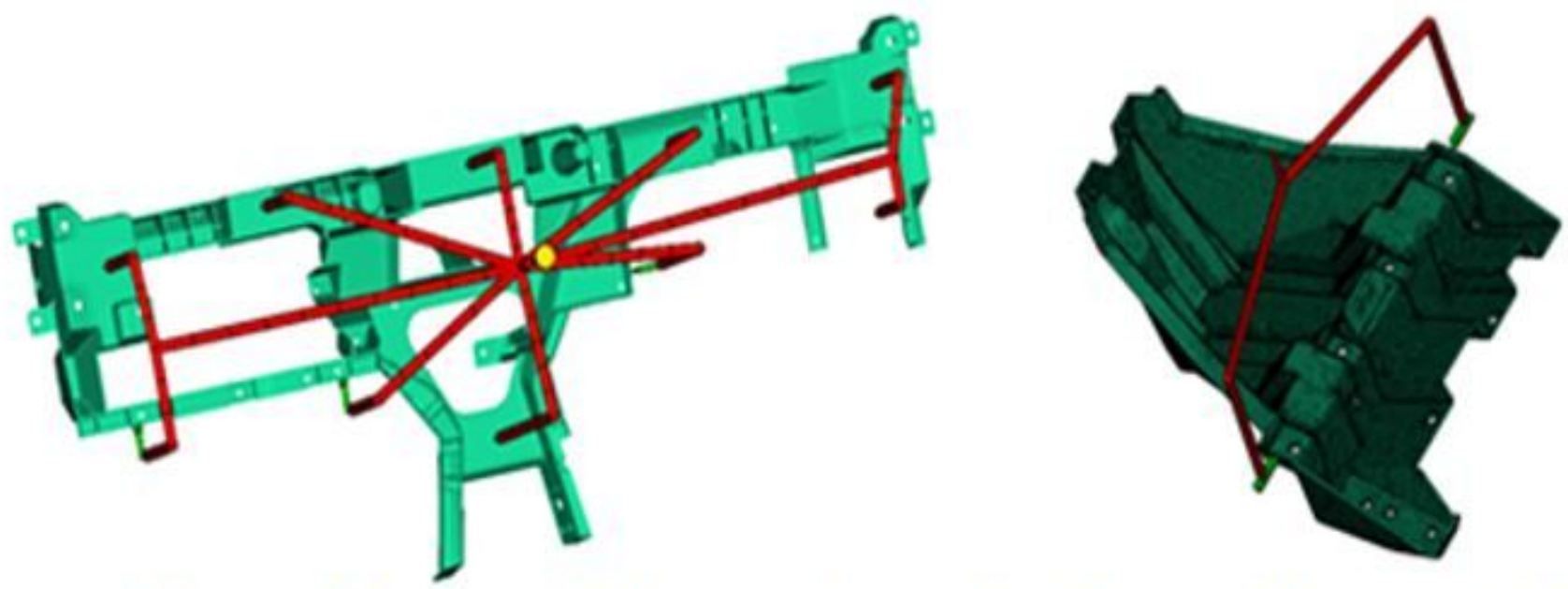

$\begin{array}{ll}\text { a. The mold gates of the steering } & \mathrm{b} \text {. The mold gates of the } \\ \text { column support assembly body } & \text { steering column bracket }\end{array}$

Figure 6

The mold gates of the Steering column support assembly 


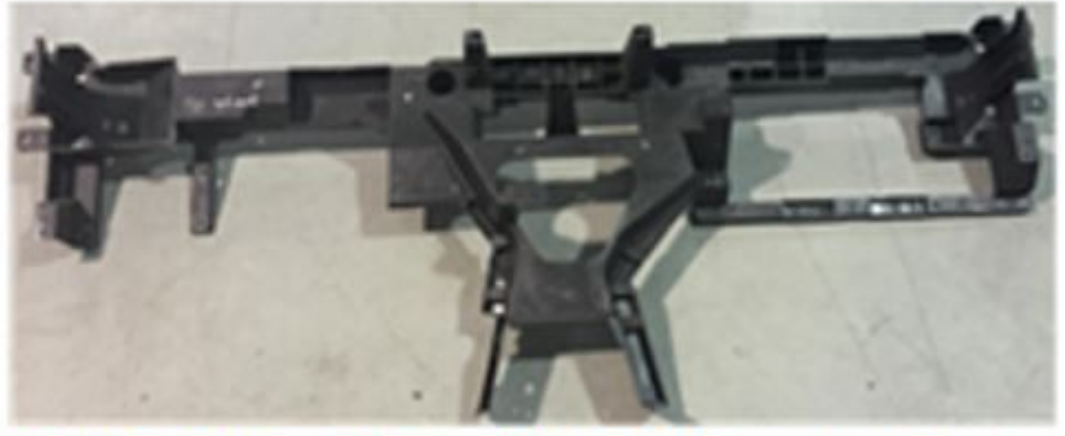

(a) The CFreinforcedPA66 steering column support assembly body

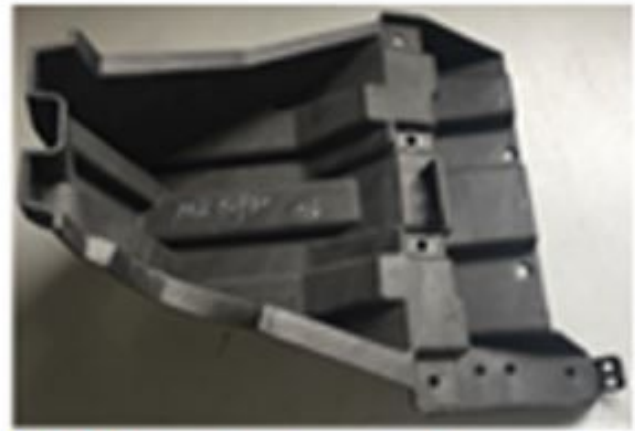

(b) The steering column bracket

a. The CFreinforcedPA66 steering column support assembly

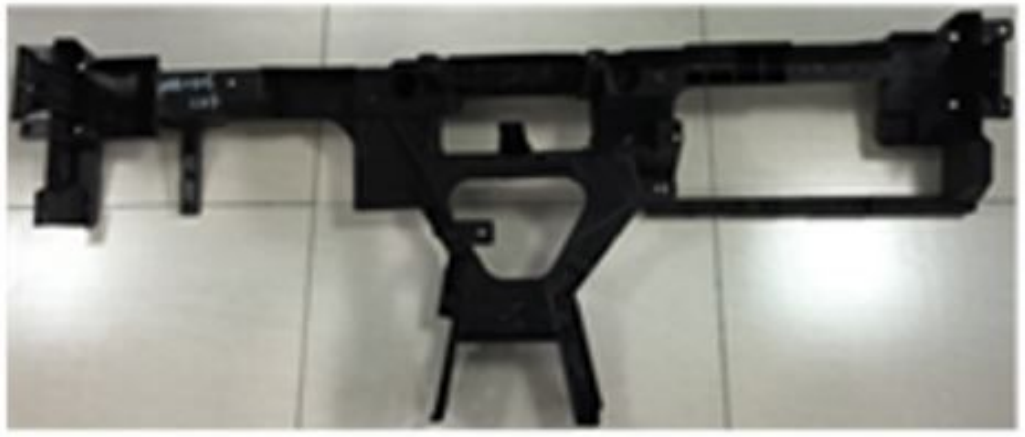

(a) The GF reinforced PA66 steering column support assembly body

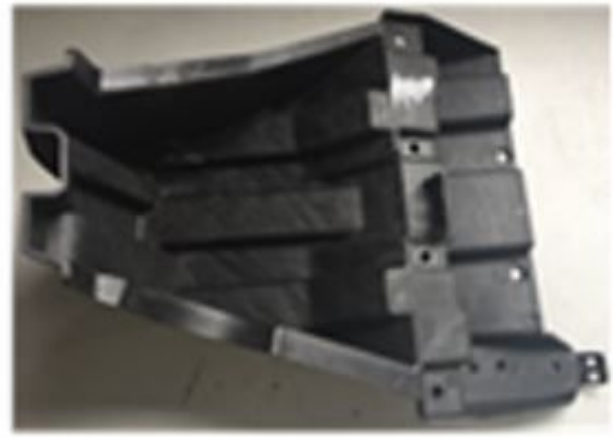

(b) The steering column bracket

b. The GF reinforced PA66 steering column support assembly

Figure 7

The composite steering column support assembly 


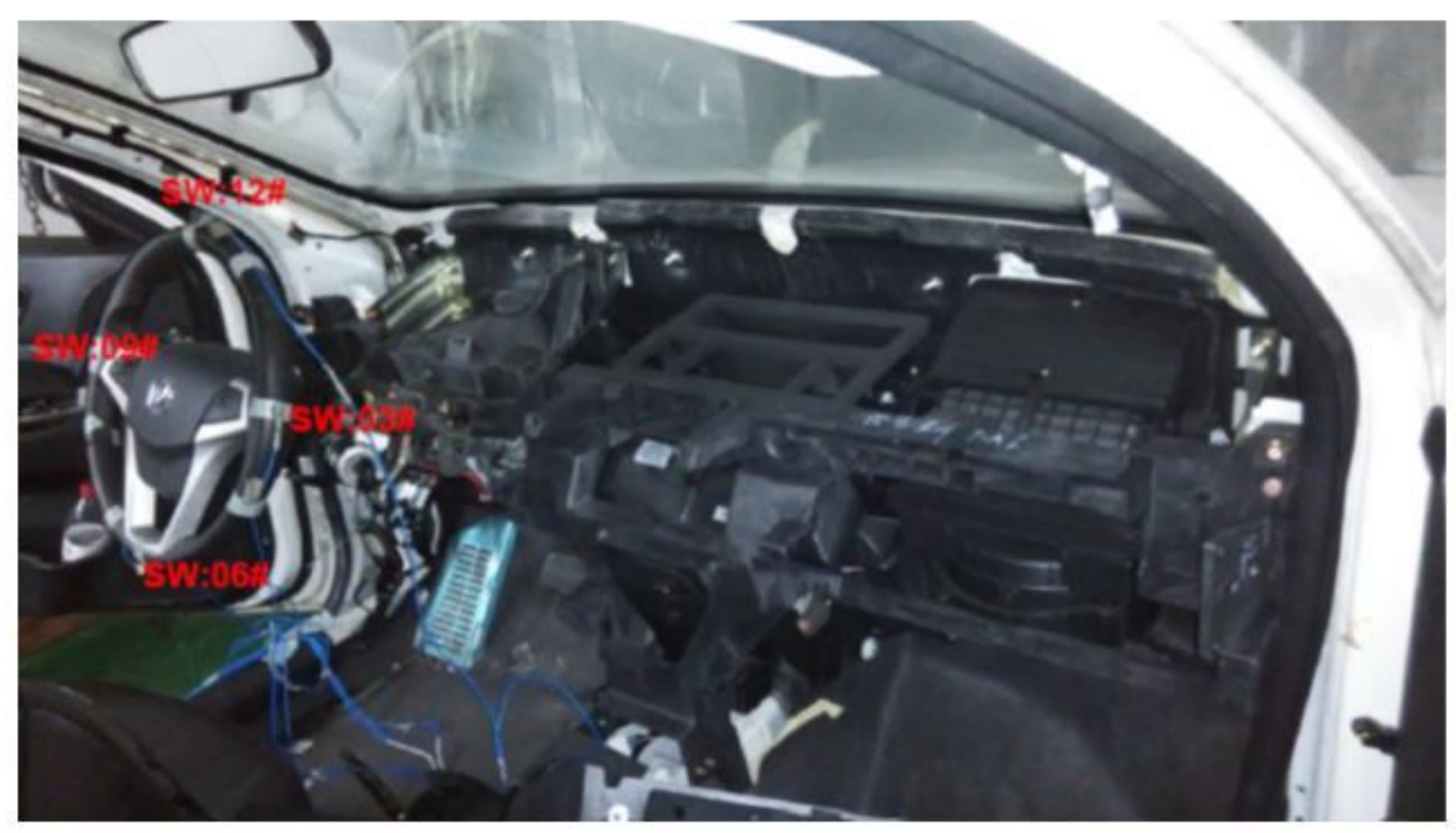

\section{Figure 8}

The steering system mode test

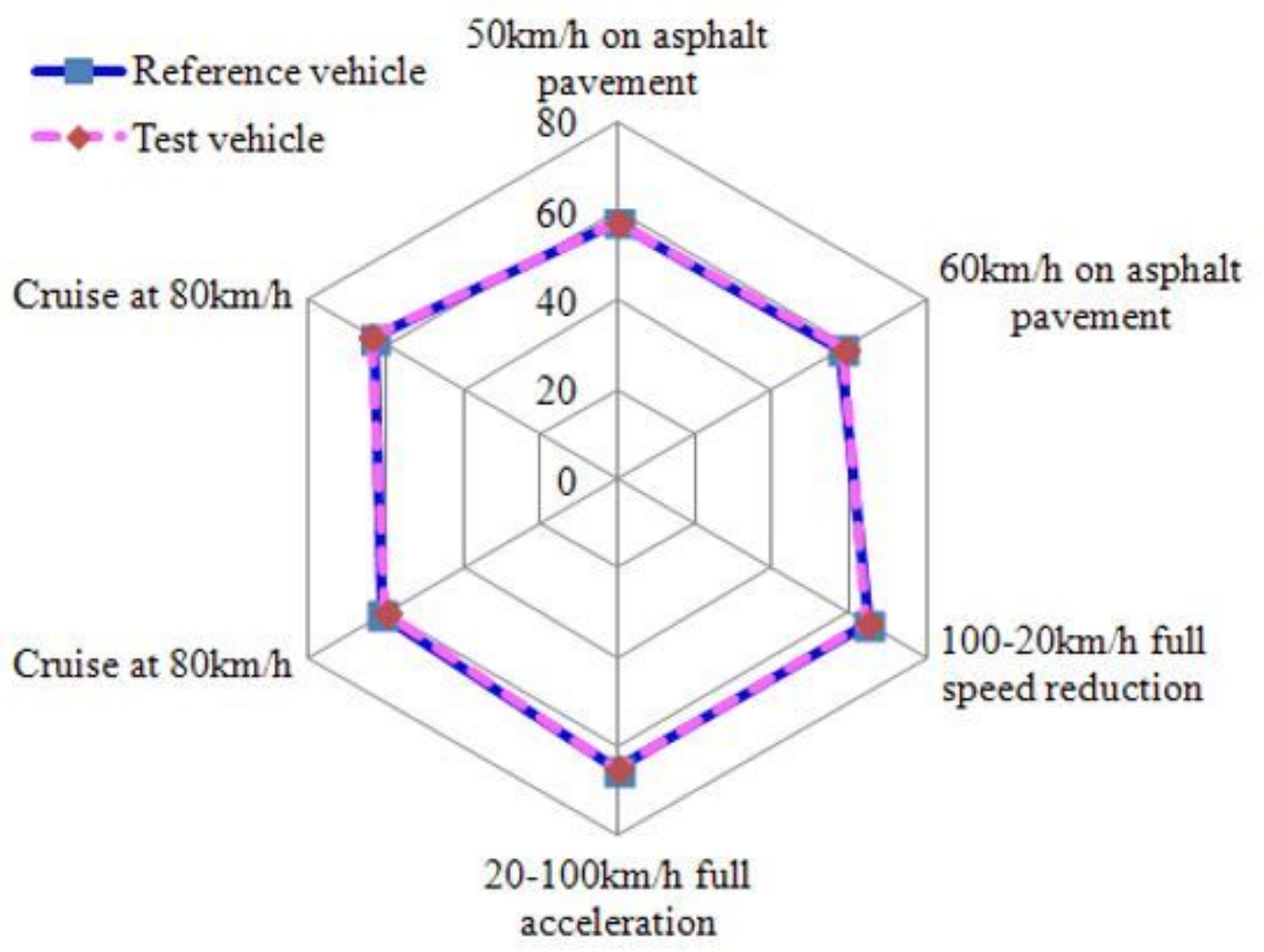

Figure 9 
Interior noise test of CFRP Steering column support assembly[17]

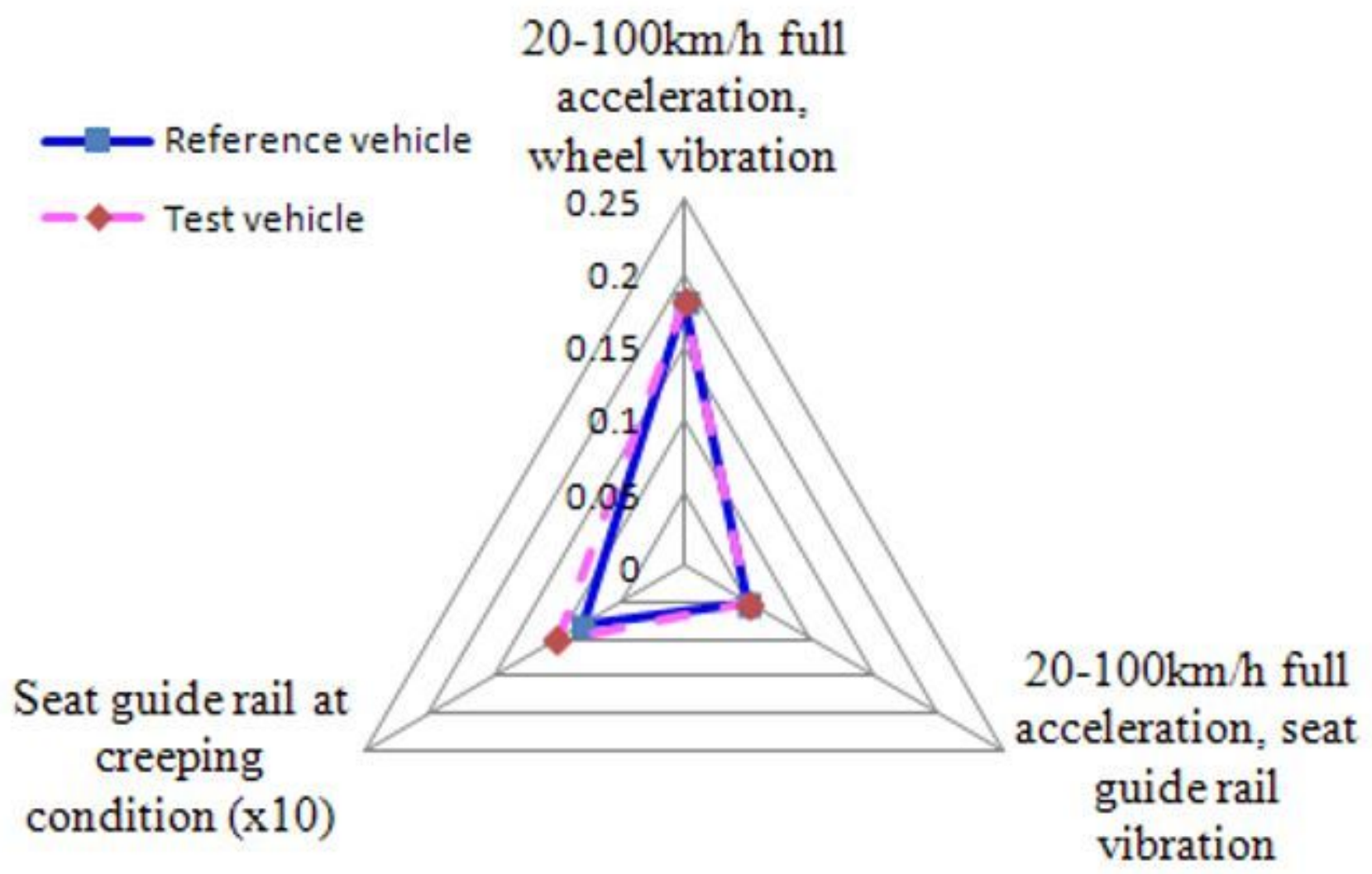

Figure 10

Vibration test of CFRP Steering column support assembly [17] 


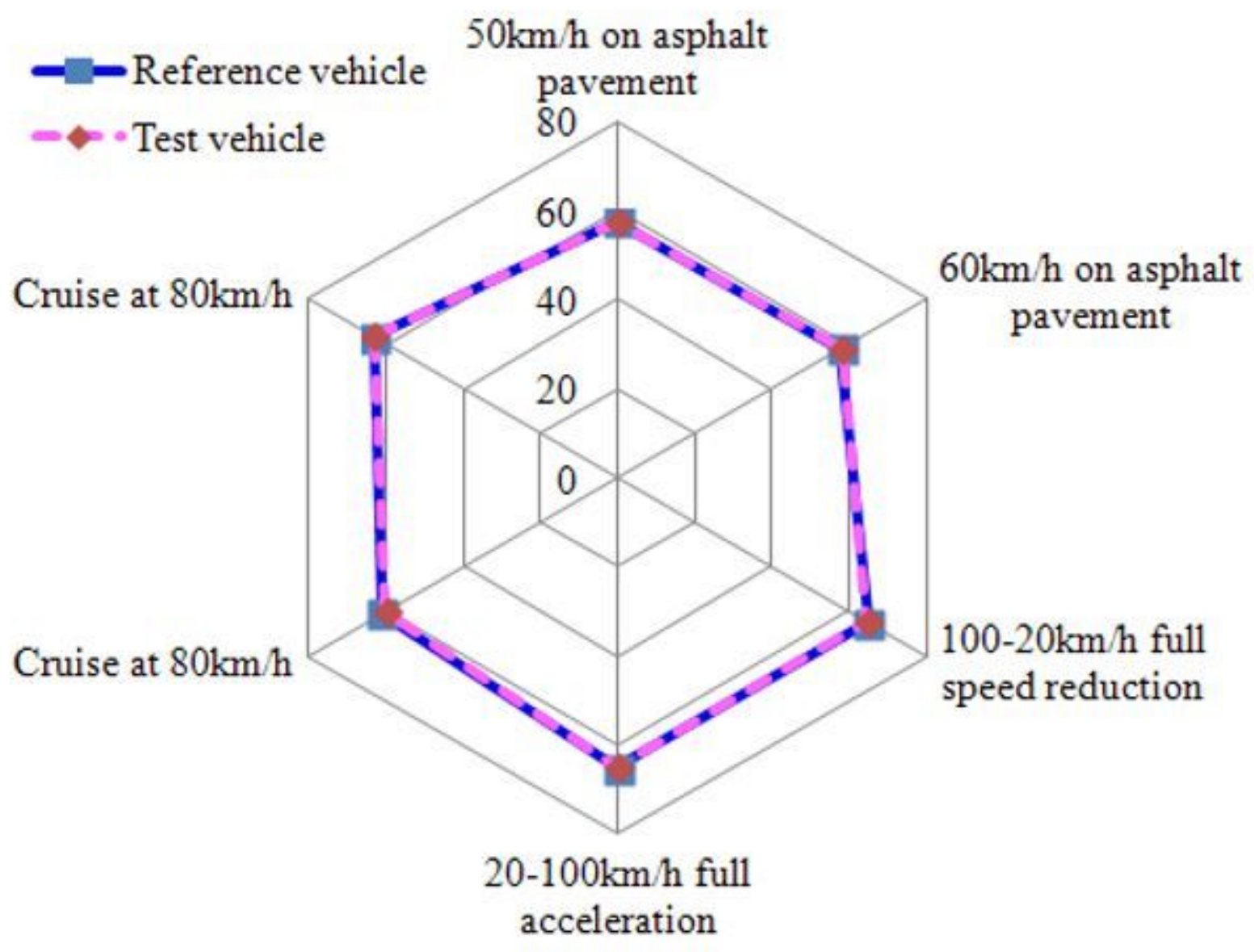

Figure 11

Interior noise test of GFC Steering column support assembly 


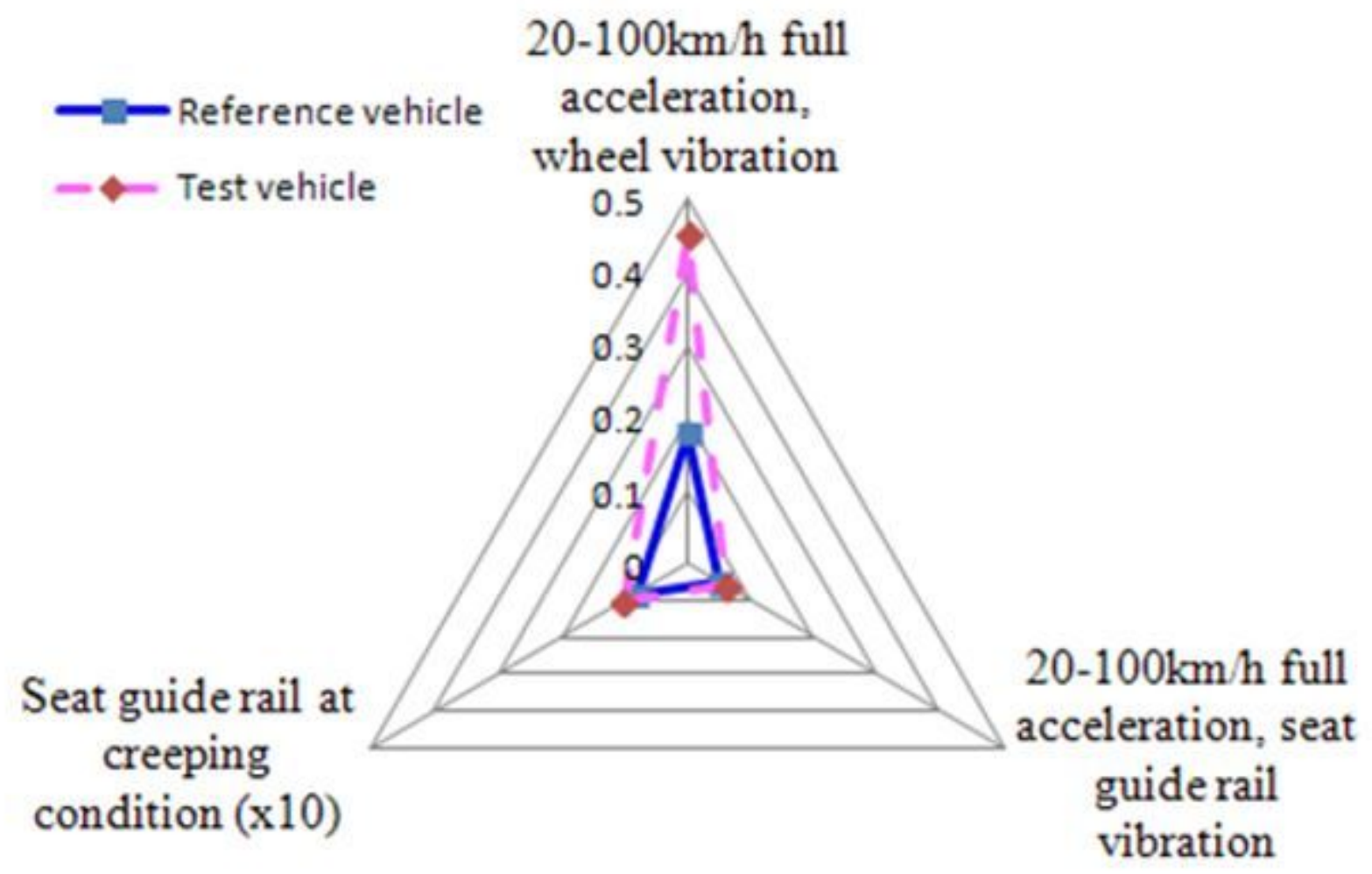

Figure 12

Vibration test of GFC Steering column support assembly 


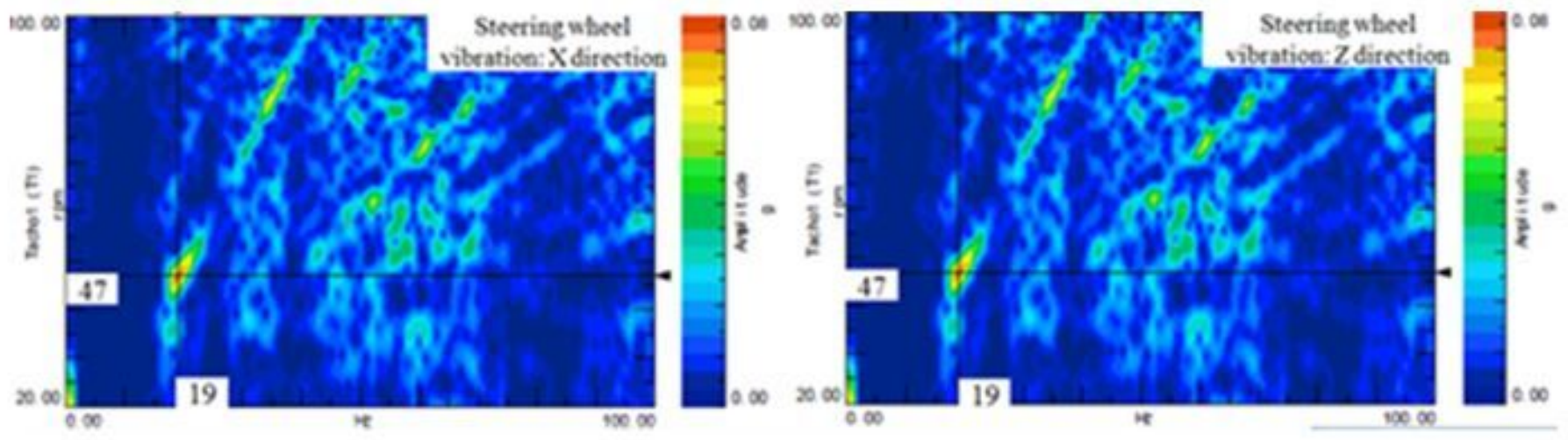

a. Steering wheel vibration of GFRC steering column support assembly at $47 \mathrm{~km} / \mathrm{h}$

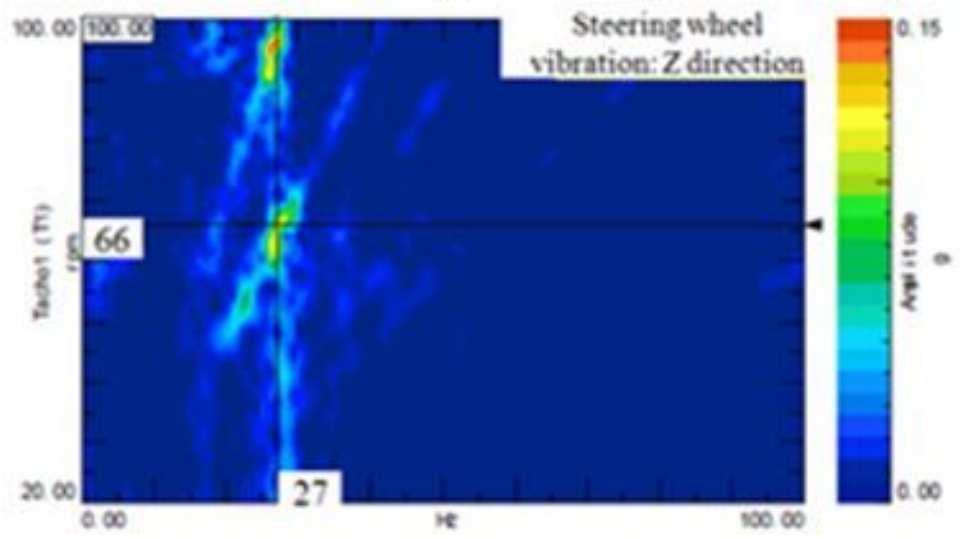

b. Steering wheel vibration of GFRC steering column support assembly at $66 \mathrm{~km} / \mathrm{h}$

\section{Figure 13}

Steering wheel vibration of GFC Steering column support assembly 
- Steering system mode requirement definition

- Steering system mode requirement of steel part

38

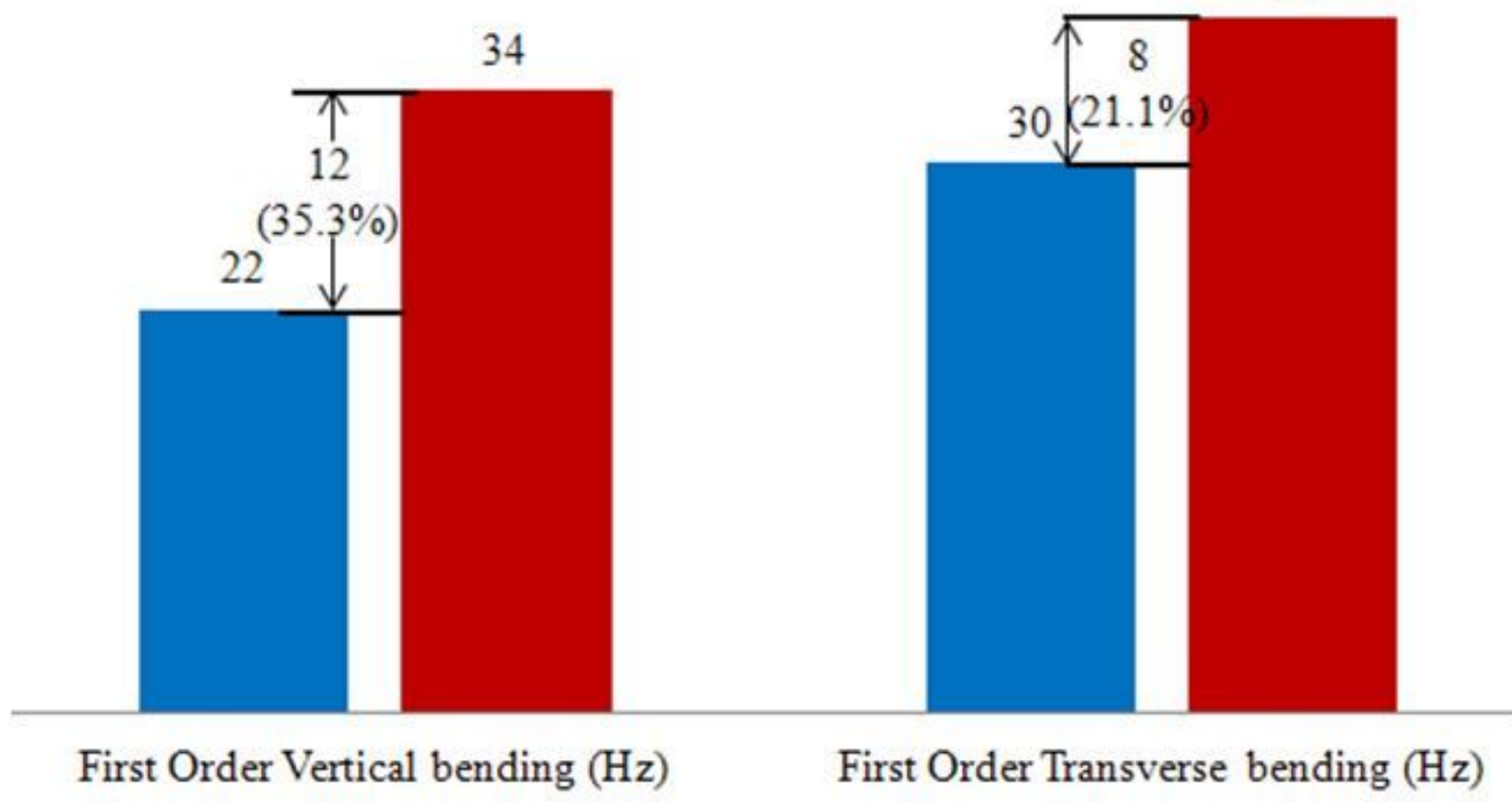

Figure 14

The comparison of the steering system mode definition 